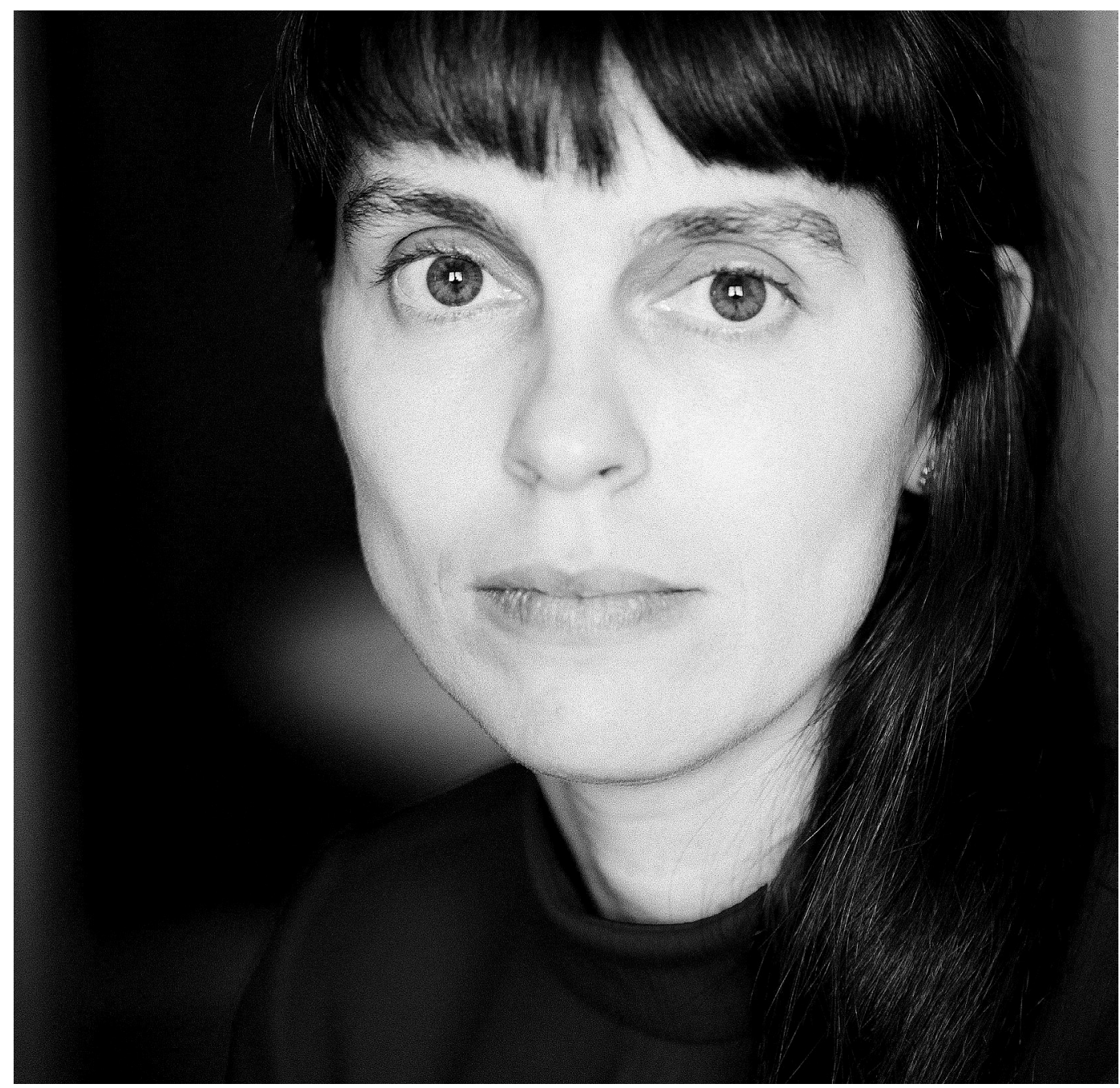

\title{
Joana Craveiro Vestindo novas linguagens em cena
}

\section{Eunice Tudela de Azevedo}

Joana Craveiro assume, há já doze anos, a direcção artística do Teatro do Vestido (TdV), função que consegue conjugar com uma carreira docente e com a frequência de um doutoramento em Londres. O projecto, de percurso sólido e coerente, nasceu em 2001, com o espectáculo Tua, a partir de uma parceria de escrita com Susana Gonçalves, e é hoje uma companhia que não se limita à apresentação de espectáculos criados a partir de dramaturgias originais. Integra ainda uma dimensão pedagógica e a preocupação com a criação de comunidades - que se revêem nas actividades complementares da companhia - bem como um esforço de procura de novas linguagens cénicas e dramatúrgicas. São estes apenas alguns dos aspectos abordados nesta conversa em que Joana Craveiro fala, também, dos mais recentes projectos do TdV.

0 teatro foi sempre algo que a acompanhou desde cedo ou descobriu-o mais tarde na vida?

Eu sempre fui ao teatro desde pequena, com a minha mãe. Vi a Cornucópia, a primeira vez, quando tinha para ai dez ou onze anos. E outros grupos na altura, como o Teatro Aberto ou a Comuna, que também via muito. Por isso, sim, sou uma espectadora de teatro desde sempre. Depois, mais ou menos com doze ou treze anos, comecei a fazer.

\section{Onde?}

$\mathrm{Na}$ altura comecei a fazer nos Escuteiros [risos]. Comecei a escrever e a fazer peças e depois fiz também um curso de iniciação teatral, no TIL - Teatro Infantil de Lisboa que na altura era ainda em Alcântara. Abriram um curso e eu e o meu irmão candidatámo-nos. Eu tinha treze anos e era um curso nocturno em que construímos espectáculos que apresentámos n' A Barraca, à meia-noite, no CaféTeatro. Portanto, foi assim que eu comecei. 


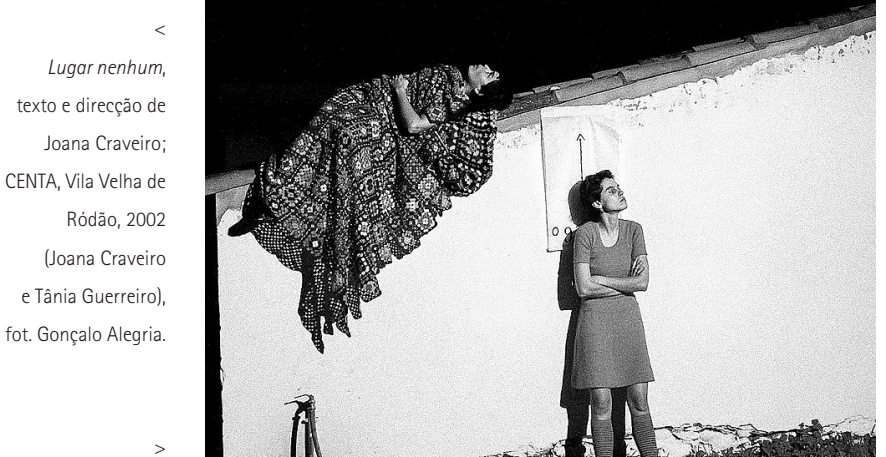

Exaustos,

textos e direcção de

Joana Craveiro;

Hospital Júlio de

Matos, Lisboa, 2005

(Inês Rosado),

fot. Miguel Esteves.

\section{Deve ter sido uma experiência fulcral, não?}

Sim, foi fulcral no sentido de ter tido contacto com as técnicas teatrais, com o fazer teatral. Numa perspectiva algo amadora, claro, mas com pessoas mais velhas também o que foi determinante, tal como a questão da apresentação a um público. Lembro-me que na altura fizemos $A$ invenção do amor, de Daniel Filipe, em bastantes sítios. Eu não tinha mais de quinze anos; por isso, sim, acho que, de certa forma, foi decisivo.

\section{Como surgiu o TdV e por que razão o baptizaram dessa} forma?

Essa pergunta... Essa velha pergunta do nome... $0 \mathrm{TdV}$ surgiu, na altura, como uma parceria de escrita que eu tinha com uma colega minha do Conservatório, a Susana Gonçalves. As duas primeiras peças foram assinadas por mim e por ela. Chamavam-se Tua (2001) e Skyscapes (2002). Na altura surgiu... Basicamente, nós queriamos escrever; escrever em conjunto. Achávamos que isso fazia sentido. Havia mais uma terceira pessoa, que era uma cenógrafa, a Carolina Vasconcelos - que hoje em dia já não faz cenografia - mas tinha sido nossa colega de Conservatório, também. E eu já não sei, sinceramente, entre as três, quem é que surgiu com esse nome "Teatro do Vestido". Não estava particularmente ligado ao facto de sermos mulheres. Não me recordo que tivesse essa conotação, recordo-me que nós pensávamos muito no teatro como uma coisa que nos despia, mais do que nos vestia. Isso eu lembro-me, nós falávamos sobre isso. Sobre esse aspecto da revelação que o teatro fazia de nós próprias. E depois acabou por ficar esse nome. Acabou por se perpetuar no tempo, já depois quando o TdV se estabeleceu como uma outra coisa, nomeadamente com a saída da Susana, ao fim de dois espectáculos. As outras pessoas do TdV questionavam, muitas vezes, o nome e queriam mudar, mas acabámos por ficar com ele, pronto. É um nome com o qual nenhum de nós tem uma relação muito forte, a não ser a relação de dez anos a usá-lo. Mas na sua origem não me parece que tenha tido uma conotação tão forte que me faça dizer que foi por esta ou aquela razão.

O TdV foi o seu primeiro projecto ou teve outros antes? Eu fui actriz do elenco do Teatro da Garagem, quando sa do Conservatório. 0 TdV aconteceu logo a seguir, praticamente. Quer dizer, estive ligada a outros projectos, por exemplo aos Primeiros Sintomas, logo no início. Traduzi uma peça com o Bruno [Bravo], que foi a primeira peça dos Primeiros Sintomas. Na escola, no Conservatório, aventurámo-nos a tentar outros colectivos, mas que

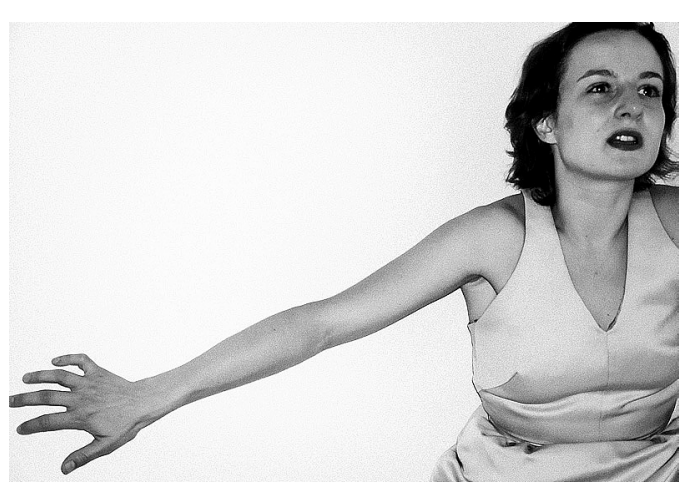

acabaram por nunca acontecer. Portanto, diria que sim, que o $\mathrm{TdV}$ é o primeiro.

Parece-me quase sempre possível a identificação de mestres ou influências no trabalho de um criador. Quais são as suas referências artísticas? Bom, a referência mais importante, para mim, é uma companhia de performance que já não existe e que se chamava Goat Island: trabalhava em Chicago e transformou-se numa outra companhia que se chama Every House Has a Door. Eu estudei com o Matthew Goulish e a Lin Hixson, em Chicago, e foi talvez a influência mais importante para o meu trabalho, embora só os tenha conhecido em 2008. Quer dizer, eu vi o trabalho deles muito antes e isso foi determinante numa série de coisas: pedagogicamente, eticamente e ao nível da criação e da colaboração.

Para além disso, encontrei pessoas em Portugal, também, claro, que me marcaram. Eu fui do Teatro da Garagem, trabalhei com o Carlos [J.] Pessoa durante alguns anos, penso que isso foi uma experiência importante do ponto de vista dramatúrgico... Do actor-dramaturgista, talvez... Não sei como chamar de outra forma. Foi importante. Tal como o foi, também, um encenador que conheci na Escócia, que se chama Maurício Paroni de Castro, com quem aliás trabalhámos agora, na semana passada, no Brasil, outra vez. O Maurício foi muito importante por todo o seu conhecimento teatral; por ter sido aluno do Heiner Müller e do Kantor, por exemplo.

Diria que os Goat Island são sem dúvida a grande referência de trabalho para mim, sim.

Se acedermos ao vosso sítio electrónico podemos encontrar a estrutura de organização do TdV. Uma coisa que constatei, ao observar essa estrutura, foi a existência de um "núcleo duro" da companhia em que podemos encontrá-la a si, mas também ao Gonçalo Alegria e à Tânia Guerreiro, juntamente com uma série de colaboradores esporádicos - uns mais frequentemente que outros. Na prática, esta organização confirma-se ou nem por isso?

Sim, a estrutura do TdV é essa. Aliás, nós chamamos precisamente "estrutura". A direcção artística da companhia é minha, mas o trabalho desenvolveu-se ao longo destes anos sempre com essa estrutura base; esse núcleo-duro, ao qual nós chamamos os "Arganazes," ou o "Concilio dos Arganazes". E depois os colaboradores... Chamamos "colaboradores" e não "estrutura" porque, de facto, neste momento é muito dificil conseguir manter uma estrutura, do ponto de vista financeiro, que seja alargada a mais do 

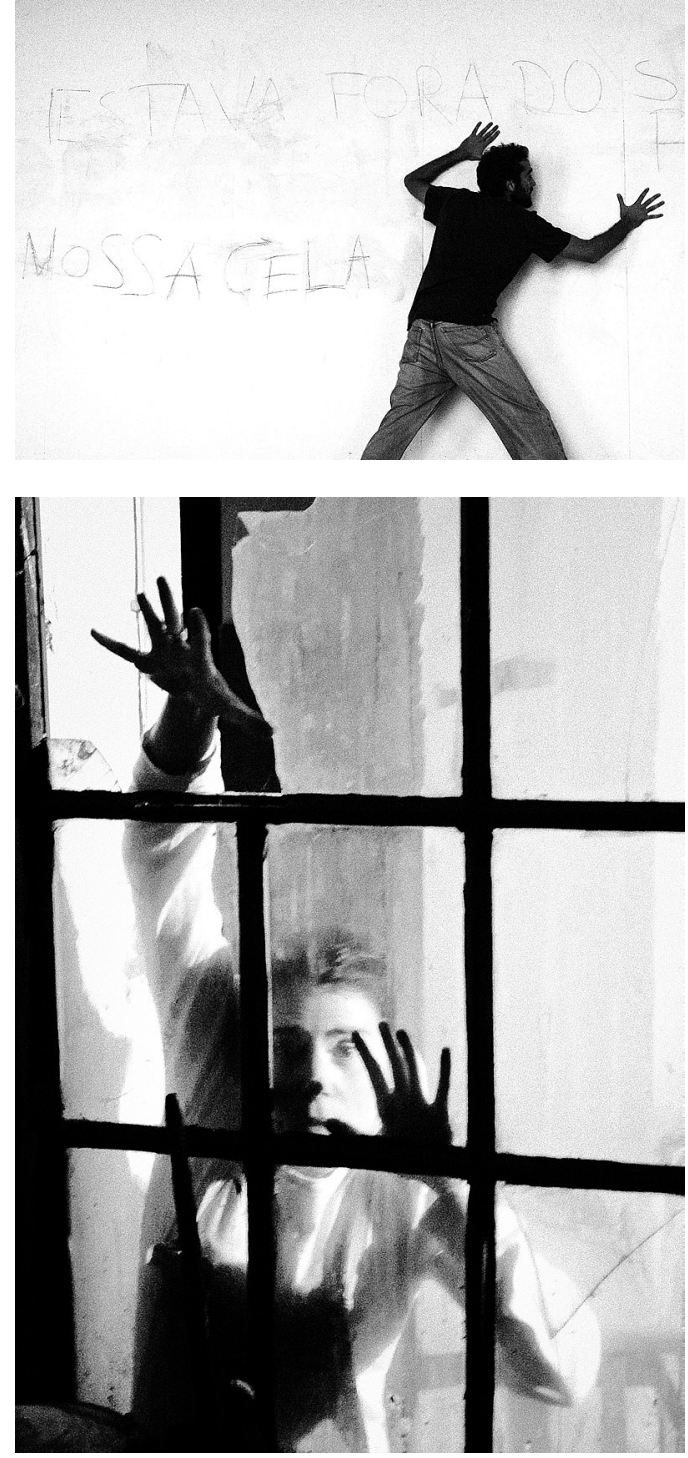

que a duas ou três pessoas. E isso é, na minha opinião, uma das grandes tragédias dos nossos tempos para uma companhia.

Do ponto de vista do financiamento às artes do espectáculo, os cortes sucessivos destroem as estruturas. Mais do que destruir os projectos, eles destroem as estruturas, na minha opinião. Nós somos uma vítima disso. Portanto, a estrutura não é maior, porque não é comportável que ela seja maior. Eu desejava que ela o fosse. Essas pessoas que consideramos colaboradores, são na verdade pessoas que têm construído o $T d V$ tanto quanto nós, que estamos na estrutura.

No manifesto da companhia podemos encontrar a ideia de um processo criativo partilhado e penso que essa ideia é reforçada quando exploramos um pouco o livro comemorativo dos dez anos do TdV. Mas, de certa forma, parece haver, em cada projecto, algum trabalho "solitário" da parte de cada criador que é depois reunido com outros para construir algo colectivo. Ou é mesmo um processo colectivo do princípio ao fim? Toda a gente tem um entendimento diferente do que quer dizer "colectivo". Para mim o teatro é essencialmente uma acção colectiva, portanto à partida o colectivo existe na

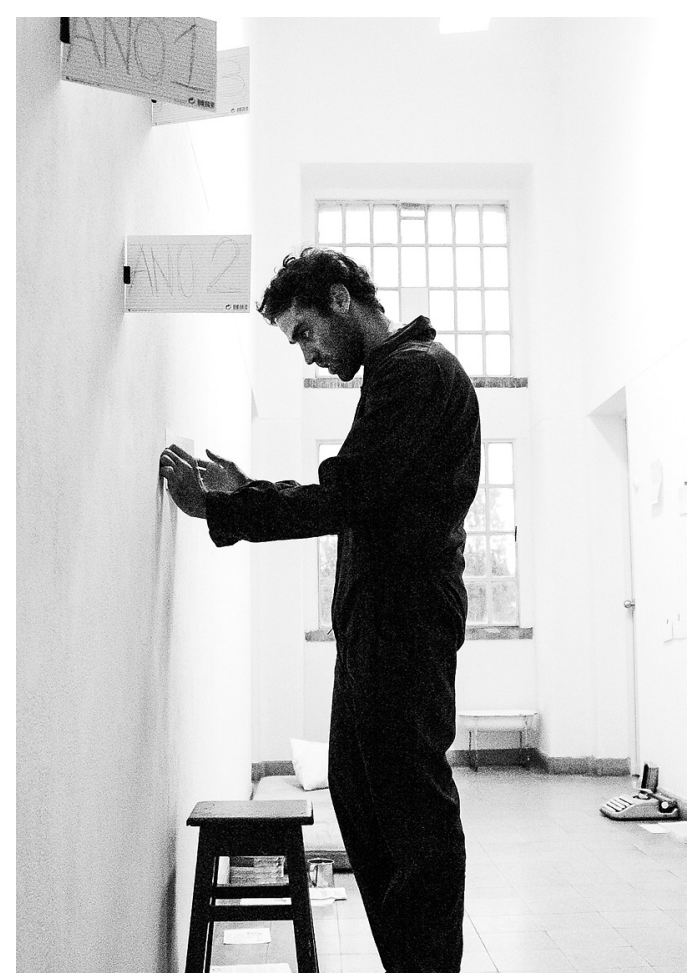

Nunca serei bom rapaz, a partir de George Jackson, direcção de Joana Craveiro.

\section{< Apresentação em} progresso no Lugar Comum - Fábrica da Pólvora de Barcarena, 2006 (Simon Frankel). $>$ Hospital Júlio de Matos, Lisboa, 2006 (Simon Frankel), fot. Catarina dos Santos.

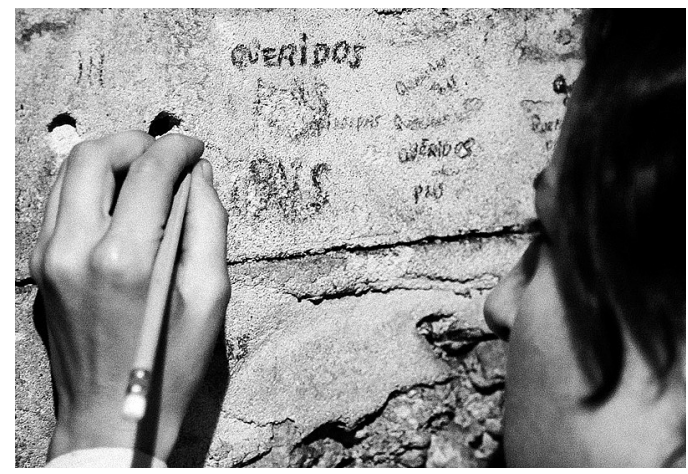

Walden,

a partir de Henry David Thoreau, texto e direcção de Joana Craveiro.

< Lagar de azeite em Colos, Odemira - Festival Escrita na Paisagem, 2006 (Tânia Guerreiro).

> Hospital Júlio de Matos, Lisboa, 2006 (Inês Rosado) fot. Catarina dos Santos. $<>$ própria definição do fazer teatral, nomeadamente se temos uma companhia e não somos artistas a solo. Podia também acontecer, mas não é o caso. Nós temos uma direç̧ão e é importante explicar isso. Não fazemos criações colectivas. Trabalhamos em colaboração, o que me parece uma coisa diferente. Quer dizer, já fizemos criações colectivas, como, por exemplo, o Monstro, parte I: Calamidade (2012), que é um espectáculo sem uma direcção assumida, em que nós os três [Joana Craveiro, Gonçalo Alegria e Tânia Guerreiro] nos assumimos como criadores colectivos daquela obra. Mas como regra, na companhia, não é esse o funcionamento.

0 que existe é: dentro do processo criativo o actor, o criador do espectáculo, traz os seus próprios materiais a partir dos quais trabalhamos. Construimos a partir daquilo que a pessoa oferece ao processo e nesse sentido chamamos-Ihe trabalhar em colaboração. Trabalhamos, também, na contaminação de materiais uns com os outros. $\mathrm{Na}$ acumulação de património... Temos isso tudo no glossário do nosso livro; todos os termos que nós usamos para descrever o nosso processo criativo.

Portanto quando fala em solitário, não reconheço essa dimensão... Talvez no sentido de que nós recolhemos as nossas coisas à noite para levar para o ensaio de 
Leitura de Walden ou a

vida nos bosques,

de Henry David Thoreau;

dir. Joana Craveiro:

vários espaços do Hospital

Júlio de Matos, Lisboa, 2006 (Inês Rosado, Simon Frankel, Tânia Guerreiro),

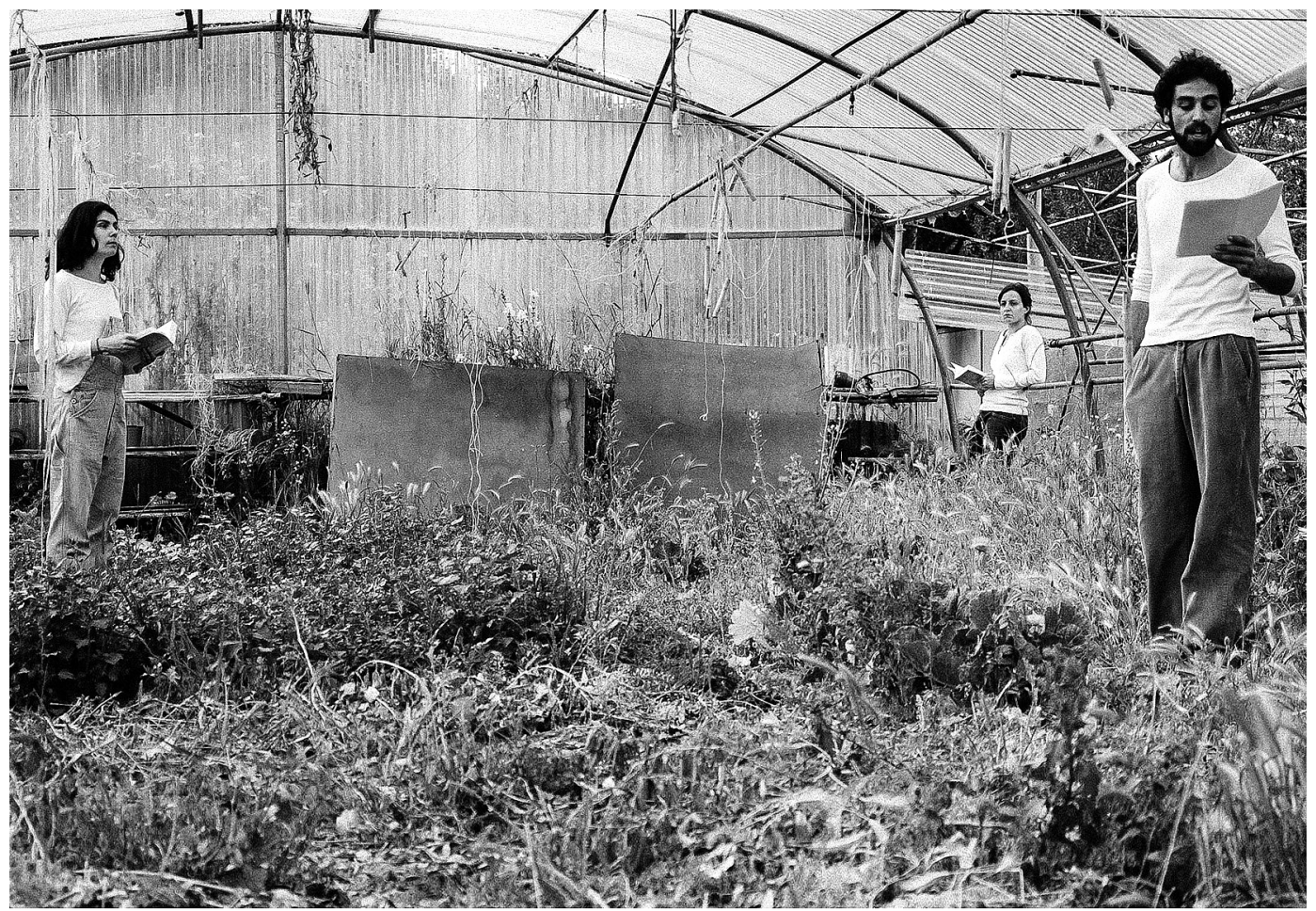

manhã... Sim, às vezes podemos preparar uma apresentação ou uma palestra para mostrar aos outros, mas de facto tudo acontece, basicamente, na sala de ensaio. Claro que há pesquisa individual; mesmo às vezes na sala de ensaio paramos por um tempo para ir pesquisar e depois reunimos ao fim de uma hora ou duas, para mostrar as coisas. Mas eu não identificaria isso como processos solitários.

Nós identificamos claramente, ou costumamos referir que cada um de nós tem a sua dramaturgia e há projectos onde isso é mais visivel do que noutros. Depois há também muitos projectos em que eu escrevo os textos a partir daquilo que eles fazem, ou escrevo uma parte para alguém que pede ou... depende.

Por isso, eu diria que é sempre colectivo, pelo facto de o teatro ser colectivo. É uma criação em colaboração que tem uma direcção e tem, claro, o lado da responsabilidade de cada um pela sua própria pesquisa, por aquilo que oferece. Falamos muitas vezes sobre isso, no $T d V$ : se nós não trazemos nada para oferecer, depois não há nada sobre o qual trabalhar. Cada pessoa tem de trazer alguma coisa, não é?

Esse processo criativo que acabou de descrever tem lugar sempre da mesma forma ou cada espectáculo tem uma maneira específica de ser trabalhado? Ele acontece sempre de forma diferente. Faz parte do nosso projecto ser um teatro, como nós dizemos, de pesquisa, com um foco muito grande sobre o processo e sobre tentar formas diferentes de fazer de cada uma das vezes. Acho que o livro também descreve isso porque fala de cada um dos projectos e julgo que se nota que para cada um aconteceram coisas diferentes. Claro que depois há metodologias e ferramentas que vão ficando. Ao mesmo tempo, eu acho que as companhias também têm que se ir reinventando, porque senão acabamos por cair sempre nos velhos hábitos.
Creio que temos conseguido até agora estabelecer diferentes maneiras de fazer para cada projecto. Isto porque as tarefas de início mudam - porque colocamos sempre uma tarefa para começar um processo. Pode ser fazer uma observação na rua, pode ser uma tarefa específica, como esperar para ser atendido na Segurança Social. Já começámos um espectáculo com formas de começar um espectáculo, por exemplo, e isso deu origem a uma série de coisas. A observação também é importante para nós. A utilização de materiais pessoais, também é outro exemplo. Sinto que os processos são sempre diferentes, mas que há momentos que são comuns a todos eles, como essa questão das tarefas ou das apresentações e palestras de uns para os outros. Portanto há coisas que são comuns, que fazem parte da nossa metodologia, mas que acabamos ao mesmo tempo por tentar não repetir ou que não nos aprisionem. Mas é uma linha subtil, não é? Entre aquilo que nos define e aquilo que acaba por nos fazer cair sempre nas mesmas fórmulas. Acho que esse é um debate e uma questão sempre premente no nosso trabalho.

Falou em tarefas iniciais... Como é que chegam a essas tarefas?

Normalmente sou eu que imagino como é que vamos começar. A cada dia que começamos um projecto, a cada primeiro ensaio, digamos assim, penso numa lista de coisas com as quais gostaria de começar e depois chego à sala de ensaio e lanço essas tarefas.

0 processo criativo é uma coisa que surge naturalmente ou às vezes é sofrido e difícil?

Não acho que um processo criativo surja naturalmente. Acho que é preciso fazer esforço e à medida que os anos passam é preciso fazer mais esforço. Sobretudo se não queremos repetir-nos e se queremos estimular também aqueles que trabalham connosco e que já conhecem os 


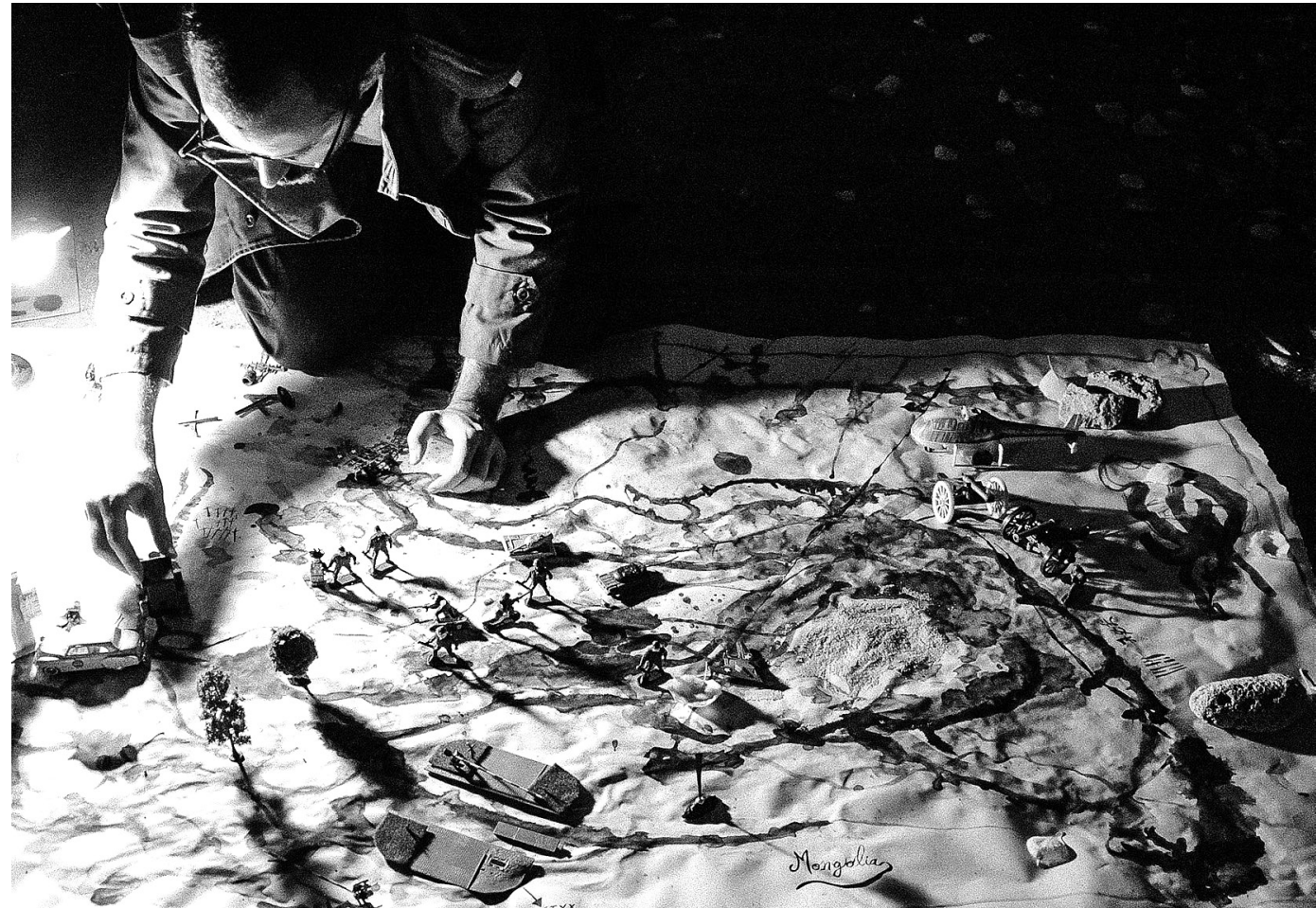

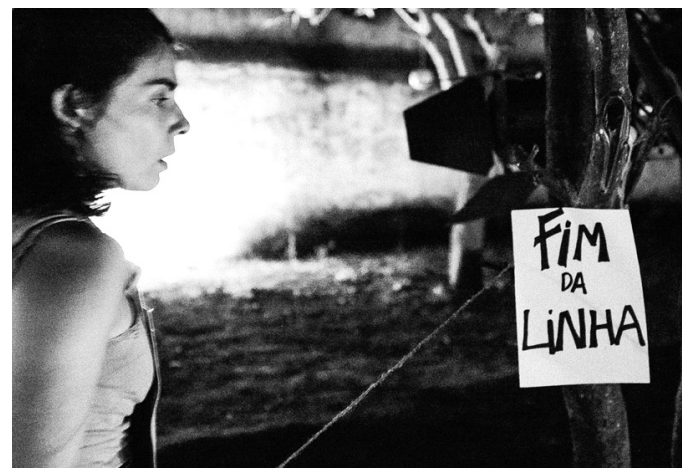

nossos "truques" e as nossas maneiras de fazer. Acho que isso é importante. Também penso que o processo não é linear. Não é uma linha que avance assim tipo autoestrada com via-verde [risos], não é isso. Há muitos momentos em que nos perdemos e momentos em que duvidamos e questionamos o que estamos ali a fazer. $E$ momentos em que somos questionados também e, por isso, acho que sim, que o processo em si é sempre difícil.

Embora, por vezes, se crie a ilusão de que é fácil e que vai correr tudo bem e que já temos a peça pronta. Nós trabalhamos muito com o ensaio corrido desde o princípio. Desde a primeira semana que trabalhamos com a ideia da duração e, portanto, vamos construindo as coisas assim e não por fragmentos. Portanto, para nós, desde muito cedo, há uma sensação de ter uma coisa quase pronta, apesar de estarmos longe disso, porque trabalhamos nessa questão da duração; do tal ensaio corrido, por assim dizer, em que experimentamos diferentes estruturas para aquilo que estamos a fazer. Acho que às vezes também há a ilusão de que o processo é mais fácil do que realmente é, porque a minha experiência diz-me que há sempre um ou vários momentos em que, de facto, se bate no fundo, e começamos a questionar mesmo aquilo que pensávamos que já estava pronto, pelo menos neste tipo de trabalho que nós fazemos.

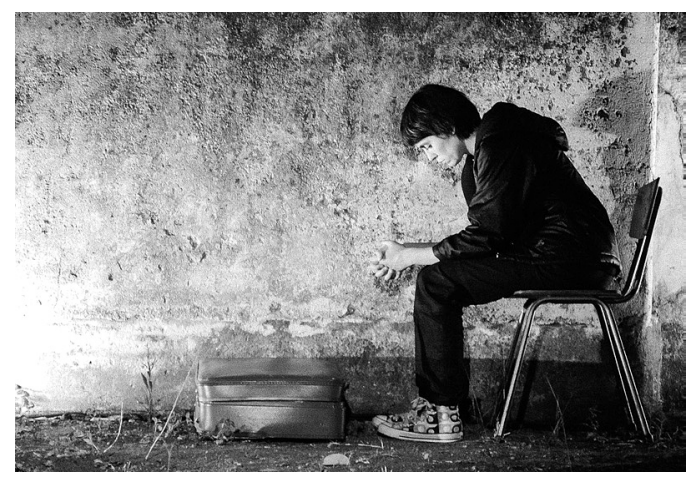

Também no manifesto está presente a ideia da criação de dramaturgia original para cada projecto. Alguma vez sentiram a necessidade de divergir em relação a esse aspecto ou é mesmo uma característica inabalável? Não, não é inabalável, mas é mesmo uma questão que nos define desde o princípio. A companhia nasceu como uma parceria de escrita e teve sempre esse lado de criação de dramaturgias como base. Nós sentimos, ou eu pelo menos sinto muita vontade, às vezes, de trabalhar autores. E já o fizemos; está registado no nosso livro. Autores que não escreveram directamente para a cena. Disso, por exemplo, sinto muita vontade. E às vezes também sinto vontade de trabalhar outros autores, mas há sempre uma questão que me coloco: o que é que eu poderia trazer de novo a essa abordagem?

E também já pedimos emprestados, por vezes, fragmentos de dramaturgias que já existem para algumas partes dos nossos espectáculos, porque fazia sentido. Com As três irmãs, por exemplo, no Ilhas (2008), porque fazia sentido, mas até agora não sentimos a necessidade de colocar em cena na integra essas peças que já estão escritas, digamos assim. Portanto, não é que seja uma questão inabalável. Se algum dia nos depararmos, penso eu, com um texto ou um autor que queiramos muito fazer,
Carta-oceano, a partir de Blaise Cendrars, criação colectiva com direç̧ão de Joana Craveiro; Évora - Festival Escrita na Paisagem, 2007 (^ Gonçalo Alegria; < Tânia Guerreiro; $>$ Joana Craveiro), fot. Catarina dos Santos. 

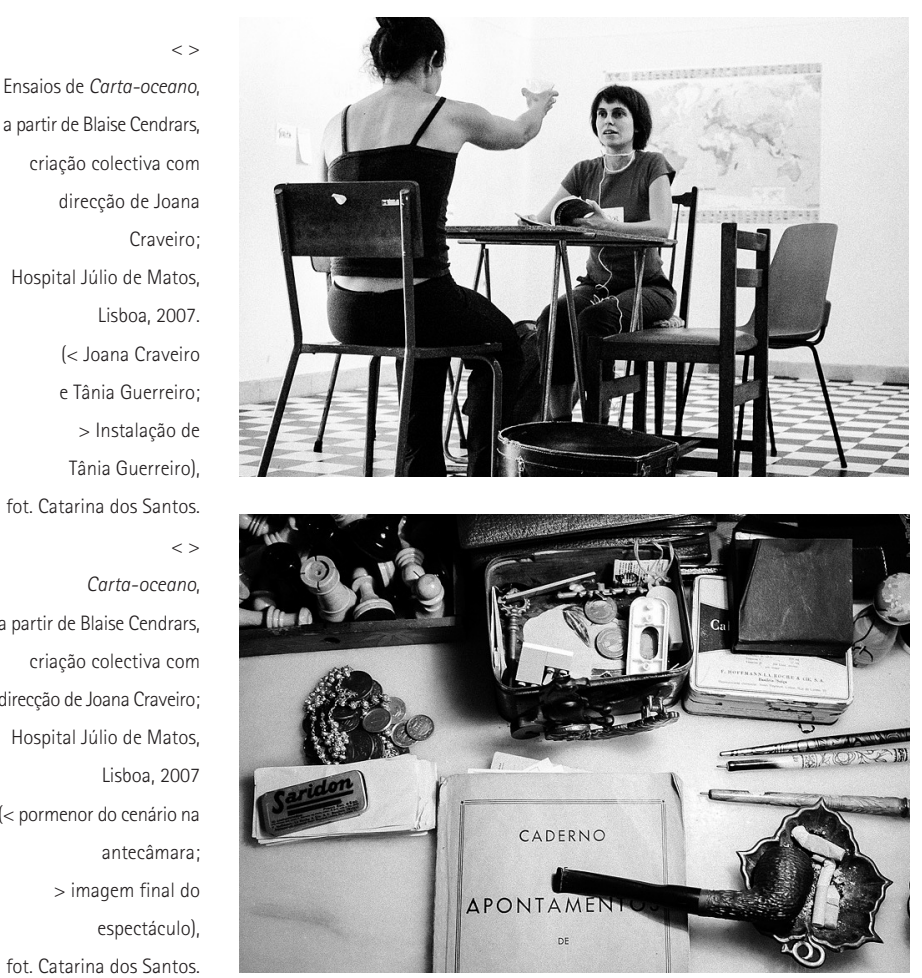

tenho a certeza de que o faremos. Até agora pareceu-nos sempre mais interessante para a nossa pesquisa pegar, por vezes, no universo de um autor.

Quando, por exemplo, trabalhámos o Maeterlinck a convite de uma companhia de teatro de Sintra - o Chão d'Oliva, a Casa de Teatro de Sintra, que nos lançou esse repto do Maeterlinck - trabalhámos a partir do universo do autor, mais concretamente a partir do universo de uma peça, mas não a fizemos. Eles também não queriam que nós fizéssemos as peças do Maeterlinck. Mas, por acaso, mantivemos até a estrutura que Maeterlinck utiliza n' 0 pássaro azul, e que nos pareceu bastante interessante. Até agora isso tem-me interessado mais do que colocar em cena a peça como ela é; que também em si é uma questão problemática, porque a peça como ela é... Não sei exactamente como é. Só sei o que é o texto escrito com as indicações do autor, mas como é que ela é só se descobre ao fazê-la em cena.

Em relação aos universos dos autores: como é que são seleccionados?

Não acho que haja um critério único. Tem a ver com aquilo que nos interessa. Às vezes pode ser aquilo que estamos a ler no momento, ou aquilo que lemos há um tempo e que nos pareceu que podiamos fazer um espectáculo sobre isso e pegamos no autor.

Quando fizemos o projecto de "literatura," composto por uma peça sobre três autoras e uma sobre três autores, estes foram escolhidos, de certa forma, intuitivamente, mas tinham ligações entre eles. E elas também. Tinham ligações entre elas. Mas há muito do acaso nisto. Do acaso do dia-a-dia. De estar vivo, de estar atento ao mundo e às coisas, para os livros e os autores que se cruzam no nosso caminho pelas mais diversas razões.

Parece-me que quase todos, se não mesmo todos, os espectáculos do TdV são marcados por alguns temas
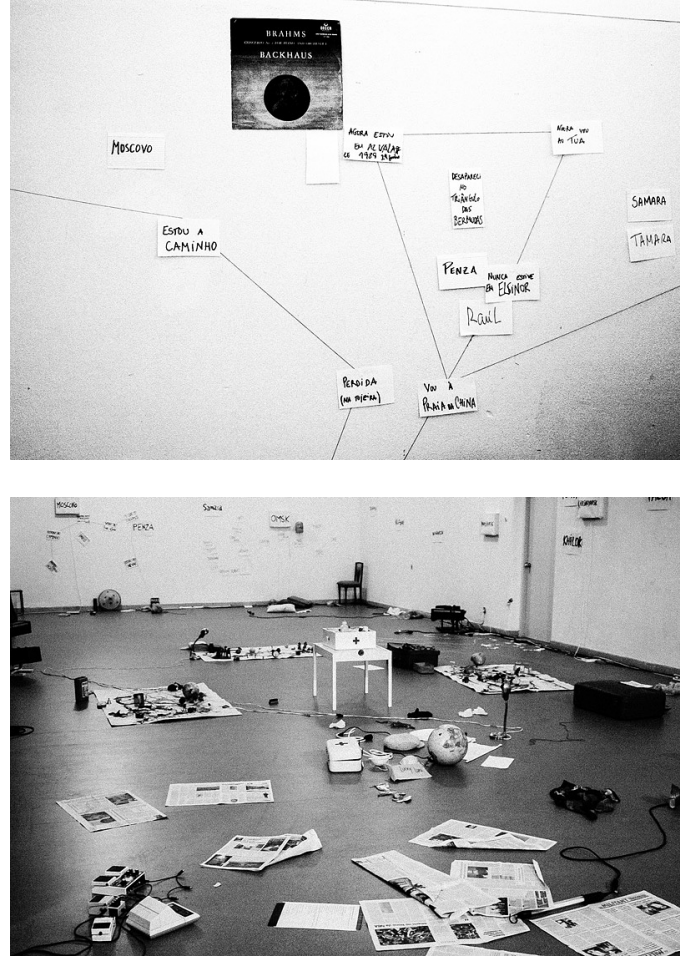

recorrentes, como a viagem ou a memória e também uma certa noção de casa. Como é que chegam à forma para tratar cada tema? Por que razão esses temas estão sempre tão presentes no vosso trabalho? Bom, a razão dos temas eu não a sei. São os temas que nos inquietam; que nos dizem alguma coisa. Correspondem muitas vezes a obsessões pessoais minhas que eu acabo por impor aos meus colegas, e que eles, de certa forma, recebem [risos]. Às vezes aceitam melhor, outras pior. Ou eu imponho sobre a minha própria dramaturgia quando estou em cena, quando estou a construir os meus materiais e acaba por ficar como uma marca.

Sobre a forma de os tratar... Não sei muito bem, acho que isso se liga com a questão das metodologias. No nosso processo de trabalho, não começo por visualizar como o espectáculo vai ser no final. Compreendo que possa haver projectos de outras pessoas que sejam assim, em que se começa com um cenário desenhado e com a visualização de como se vai implementar em cena determinada peça. Nós, de facto, trabalhamos no oposto disso, porque trabalhamos a partir do nada. Quer dizer, não é exactamente do nada: é a partir de um tema, de um autor, mas trabalhamos realmente a criação de raiz. Quando nós usamos esta palavra, ou expressão - de raiz - ela tem uma realidade muito palpável, que é esta de se chegar ao primeiro dia de trabalho e, claro, há uma tarefa para começar, mas eu não tenho na minha cabeça uma visualização clara de como vai ficar o espectáculo final. Se não fosse assim, seria, talvez, um pouco falacioso usar o termo teatro de criação ou devising, porque não o estariamos a fazer; estariamos a fazer uma outra coisa. Da minha parte, eu quero acreditar sempre que aquelas pessoas com quem eu trabalho - que são criadores vão trazer para o processo qualquer coisa que me surpreenderá e que ultrapassará quaisquer expectativas que eu possa ter anteriores a algo que eu queira colocar em cena. 


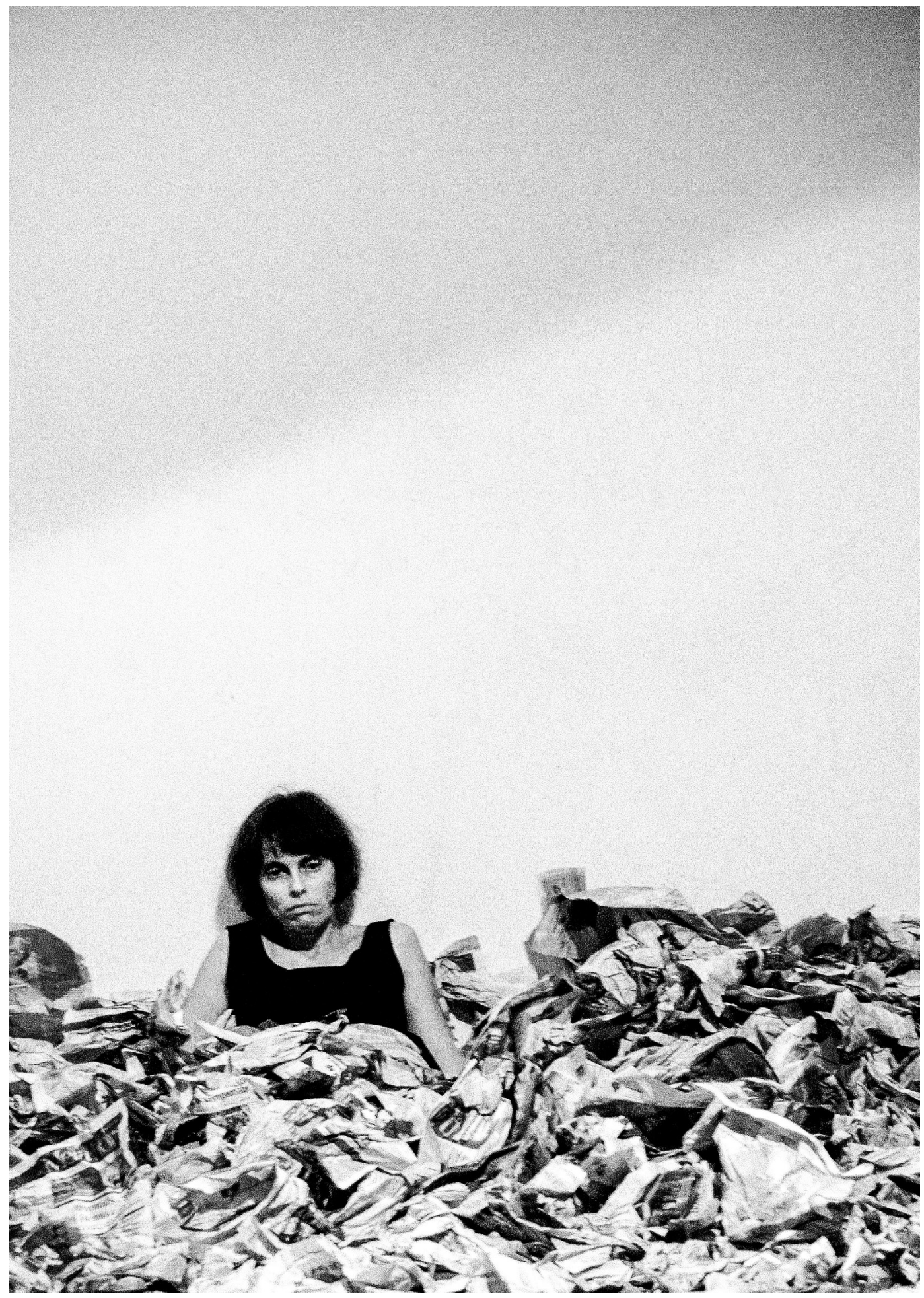

Claro, posso começar com uma imagem. Por exemplo, eu tinha desde o princípio uma imagem para o Paredes de vidro (2013), que era a de utilizar uns fios - fio de norte - e esses fios estão lá no espectáculo. Essa imagem era anterior ao processo de trabalho, mas por que razão ela aparecia eu não sei. Gosto do material, fazia-me sentido na ideia de viagem, do percurso daqueles três actores, e acabou por acontecer e está no espectáculo. Mas como é que essa imagem depois se traduz em cena, isso depende absolutamente dos criadores com quem trabalho. Não faria sentido ser eu a impor isso, embora depois dirija,
Ilhas,

criação colectiva com

direç̧ão de

Joana Craveiro;

Negócio/ ZDB, Lisboa,

2008

(Joana Craveiro),

fot. Filipe Dâmaso da Silva. durante o processo, as ideias que eles têm. Acabo por conduzi-las, ou estruturá-las, ou fazer a dramaturgia para que depois tudo se traduza num todo coerente. Por isso, essa pergunta sobre se muda a forma de trabalhar cada uma das coisas... 0 que acho que muda é a maneira de começar, algumas metodologias, as tarefas que eu imagino para cada um dos trabalhos.

Por exemplo, para Esta é a minha cidade e eu quero viver nela (2012), no Porto, criei uma estrutura à partida. Cheguei ao primeiro dia de ensaio e sabia que queria trabalhar com solos e gostava que cada um deles 


$$
\begin{array}{r}
\text { Ilhas, } \\
\text { criação colectiva com } \\
\text { direção de Joana } \\
\text { Craveiro; } \\
\text { Bomba Suicida, Lisboa, } \\
2008 \text { (Gonçalo Alegria, } \\
\text { Joana Craveiro, } \\
\text { Simon Frankel } \\
\text { e Tânia Guerreiro), } \\
\text { fot. Vera Carmo. }
\end{array}
$$

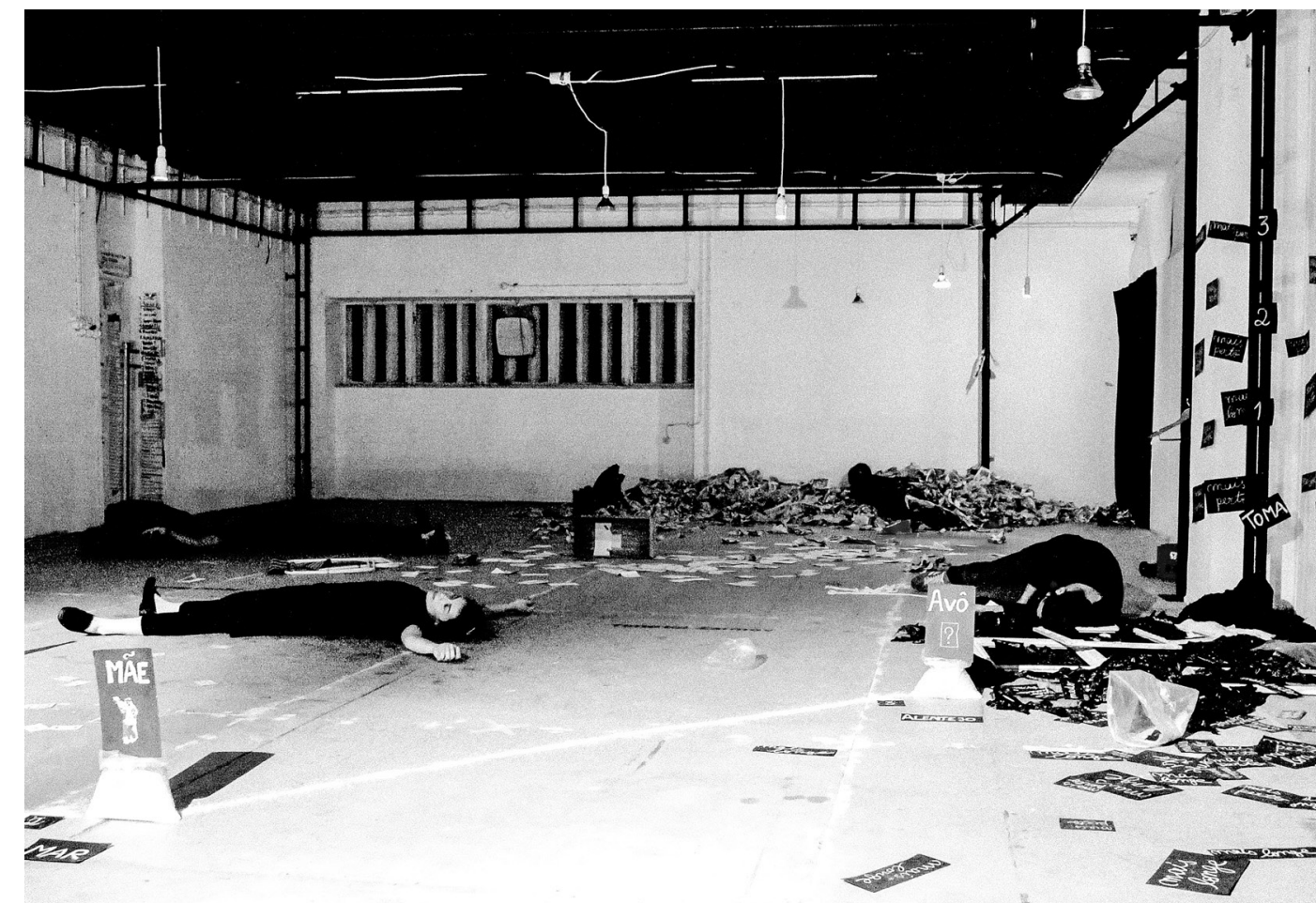

desenvolvesse a sua própria viagem de 15 minutos. Isto é a estrutura e depois trabalhamos com ela. A partir dai lanço uma série de tarefas que conduzem a isto, mas nunca imaginaria na minha cabeça como é que aquilo ficaria no final. Ao fim de uma semana já posso começar a imaginar, mas no primeiro dia não. Fico na expectativa da surpresa que advém da tarefa ou ideia que lanço. Penso que isso é o trabalho de criação.

0 espaço parece-me ser um elemento bastante importante para o TdV. Qual o seu verdadeiro impacto na construção do espectáculo? 0 que é que vem primeiro: o espaço ou o espectáculo?

Já aconteceu de tudo. Acho que o espaço é determinante para qualquer companhia, porque normalmente uma companhia não tem espaço, portanto acho que acaba por ser uma questão também política; a questão do espaço no sentido de onde trabalhamos, como trabalhamos. Para nós, desde cedo, talvez por essa condição de sem-casa, o espaço foi sempre determinante e determinou muitas vezes as peças. Gostámos muito, e gostamos, de trabalhar em função dos espaços, mas isso nem sempre é possível. Nem sempre é possivel termos o mesmo espaço para ensaiar e apresentar o espectáculo.

Quando trabalhámos no Hospital Júlio de Matos, por exemplo, durante dois anos, as peças foram praticamente todas ditadas pelo espaço, que teve uma grande influência na construção dos espectáculos, nas opções de encenação, porque era realmente um espaço muito rico, muito diverso e diferente de um espaço convencional. Seja a cave, ou a estufa, cá fora; os salões, as alas ou um corredor, onde fizemos um espectáculo que se chamava Nunca serei bom rapaz (2006). Fizemo-lo num corredor da ala, onde só cabiam seis ou sete pessoas, por exemplo. Isso foi determinante. Quando fazemos o Esta é a minha cidade... a cidade [em causa] é determinante; os espaços da cidade são determinantes. E depois quando fazemos em salas com uma estrutura mais ou menos convencional, de certa forma, isso também é decisivo, porque essa relação com o público - à italiana - é determinante, bem como o facto de ser uma sala com certas condições ao nivel da iluminação ou do som que proporciona outro tipo de opções. Lembrome, por exemplo, do Fora de casa por agora (2010), que é uma peça do Gonçalo [Alegria], encenada por ele, em que o espaço de ensaio foi determinante, mas depois não a apresentámos lá. Era o Palácio do Marquês de Tancos, que foi fulcral para o processo de trabalho de construção das personagens, da dramaturgia, de tudo. Depois, quando fizemos no [Instituto] Franco-Português era outra coisa. Aquele espaço do nosso ensaio, que o público nunca viu, ficou gravado em nós, bem como o processo que nós vivemos nesse sítio. Por isso, sim, os espaços são sempre determinantes, embora de maneiras diferentes.

A nossa condição de sem-espaço - algo que ainda é uma batalha -fez com que nós criássemos esta relação com estes sítios. Até a relação com o não ter, como por exemplo, não ter sequer um espaço para ensaiar. Já nos aconteceu termos de ensaiar na rua, por exemplo, no parque de estacionamento da Pontinha (que já nem existe), mas que nos permitiu criar uma cena para um espectáculo o Exaustos (2005). Quando fazíamos essa cena no espectáculo, uma e outra vez, lembrávamo-nos sempre do sítio onde a tínhamos criado, mais do que do sítio onde a estávamos a fazer naquele momento.

Já aqui foram referidos os colaboradores. Como nascem essas parcerias? Por convívio, por convite, por uma vontade de trabalhar com determinada pessoa...? Bem, é um bocado por todas essas razões. Cada pessoa que trabalha connosco veio por razões diferentes. Não fazemos audições, normalmente. Não aconteceu até hoje. Acabámos por conhecer as pessoas, muitas vezes, por terem trabalhado connosco, como quando tínhamos o projecto pedagógico Zonas, por exemplo. Conhecemos 


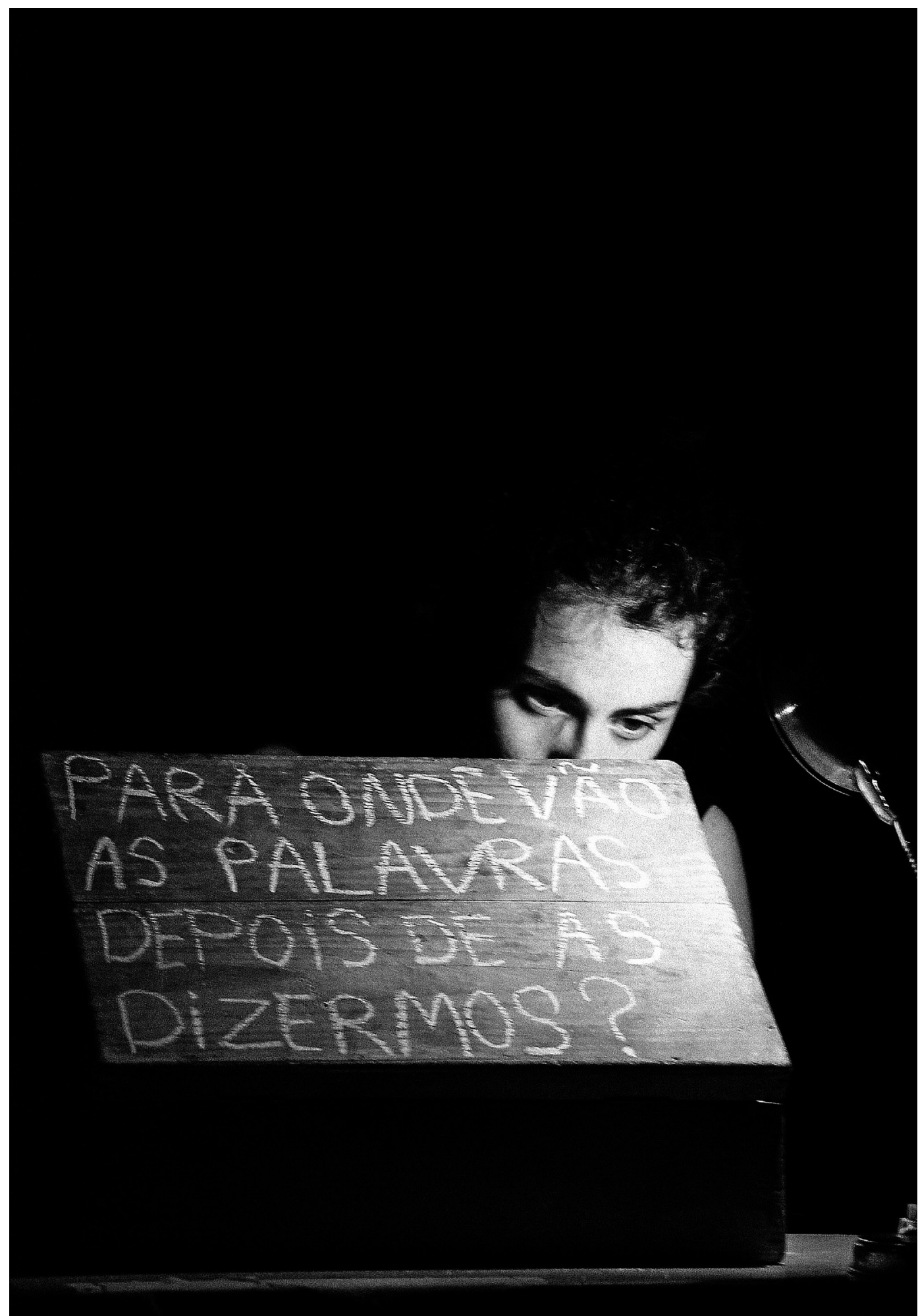

Porque na noite terrena sou mais fiel que um cão a partir de Elizabeth Bishop, Margaret Atwood Marina Tsvetaeva, textos e direç̧ão de Joana Craveiro;

Teatro da Comuna, 2009 (Tânia Guerreiro), fot. Filipe Dâmaso da Silva.

muitas pessoas que trabalharam connosco e com quem criámos afinidades. Eu, também, dei aulas - dou aulas, ainda -, mas dei aulas no ESTC [Escola Superior de Teatro e Cinema] durante algum tempo, também na Universidade de Évora e agora sou docente da ESAD [Escola Superior de Artes e Design], nas Caldas da Rainha. Em todos estes sítios conheci muitos futuros actores, digamos assim. Alguns deles são nossos colaboradores hoje em dia.

Acho que as pessoas vieram trabalhar connosco devido ao interesse que houve de parte a parte. Ou seja, o interesse delas pelo nosso trabalho, o nosso interesse pelo trabalho delas. Creio que é uma questão de criação de afinidades. E não basta só haver esse interesse, é necessário que estejam preparadas para os métodos que nós temos para propor, pois sabemos que eles não são fáceis e que exigem muito do actor, do criador que está a trabalhar connosco. Seja porque o texto vai sendo construido, ou porque há toda essa implicação pessoal e muita insegurança, às vezes, durante o processo e, portanto, é preciso alguém que esteja disposto a embarcar nisso. 

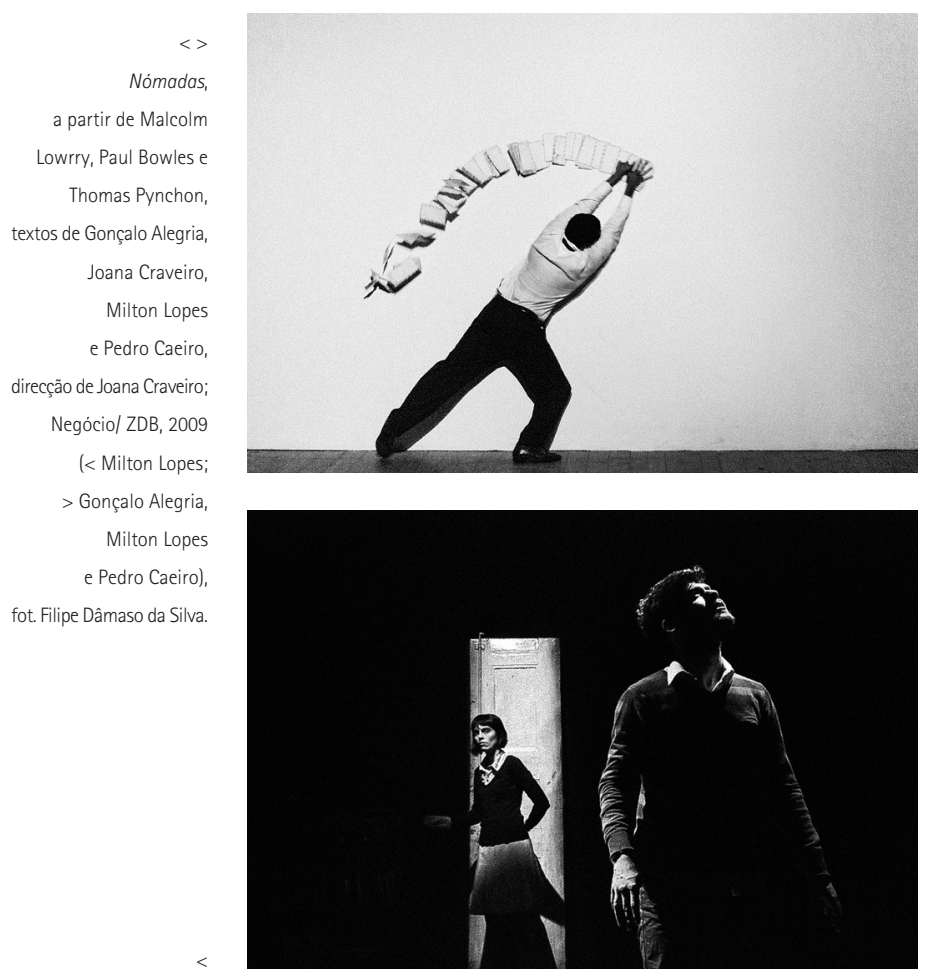

Fora de casa por agora, textos de Gonçalo Alegria,

Joana Craveiro

e Pedro Caeiro direcção de Gonçalo Alegria;

Instituto Franco-

Portuquês, Lisboa, 2010

(Joana Craveiro

e Pedro Caeiro) fot. Filipe Dâmaso da Silva.
Cada pessoa que colabora connosco surgiu de maneira diferente, mas em todas as histórias houve um momento em que nós tomámos contacto com o trabalho uns dos outros. E houve esse interesse, essa curiosidade pela possibilidade de uma actividade em conjunto. Estamos sempre à procura de alargar a nossa comunidade, que é uma noção muito importante para nós, mas mais ainda no nosso projecto de companhia - essa ideia de criar mais afinidade com cada vez mais pessoas que se traduzam em parcerias de criação.

Referiu a docência. De que forma é que essa actividade influencia o seu trabalho?

Bom, isso tem toda a influência, porque eu acho que quando damos aulas, e gostamos disso, há todo um léxico, uma forma de funcionar que se desenvolve, seja de respeito, tolerância ou formas de conseguir extrair o potencial que as pessoas têm. Acho que a docência estimula isso. Não só eu, mas todos nós no TdV, nomeadamente na estrutura - o Gonçalo, a Tânia e eu -, adoramos dar aulas e por isso tínhamos o projecto pedagógico Zonas, que nos enriqueceu tanto a nós quanto às pessoas que nele participaram e por quem nós temos, realmente, muito respeito e gratidão, porque aprendemos mesmo muito com elas. Para além disso, há o trabalho de docência que tenho desenvolvido em cursos superiores de Teatro, nomeadamente desde 2007 como docente na ESAD. Mas, claro, faço coisas nas minhas aulas que são muito diferentes das que faço no $T d V$, porque compreendo que são espaços diferentes para colocar metodologias diferentes em prática. Mas acho que é determinante em todos os aspectos, sim.

Referiu o projecto Zonas. Em que consistiu? 0 projecto Zonas era um laboratório de criação que acontecia durante três meses, com vários temas diferentes. Começou como um projecto de aulas de interpretação, quando deixei de dar aulas na ESTC, em 2006, mas depois

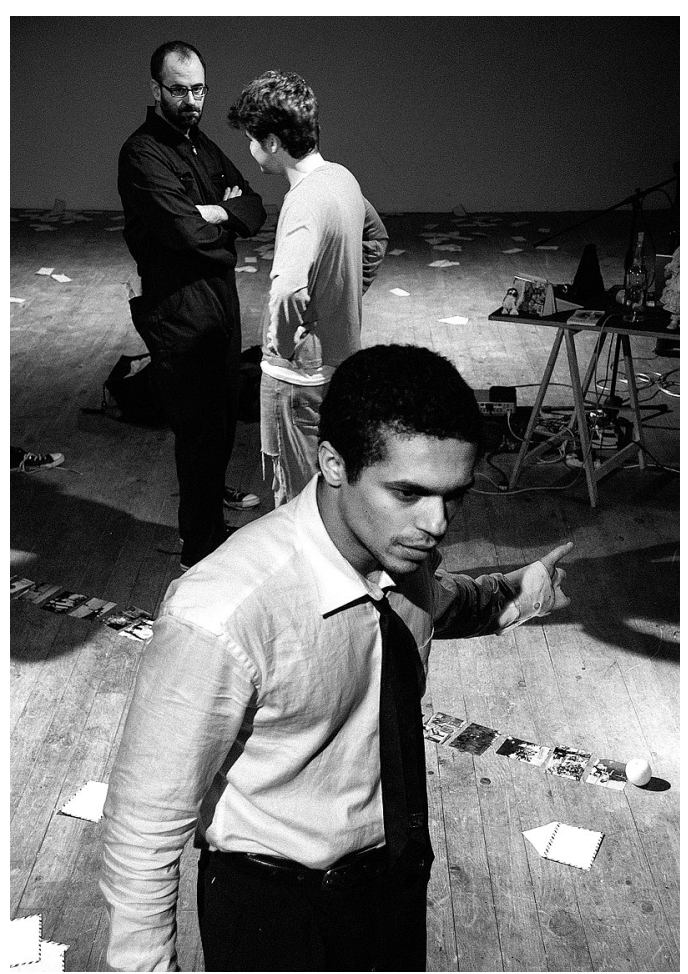

foi-se definindo cada vez mais como um espaço para os participantes criarem em liberdade, de uma forma de acompanhamento e com feedback dado por nós. Ajudávamo-los a colocar em prática as suas ideias, sempre num ambiente que fosse, acima de tudo, de apoio e de motivação, mais do que um ambiente de crítica e de destruição da criação. Criámo-lo como um projecto que, de alguma forma, se opunha a certas formas pedagógicas que nós considerávamos destrutivas da criação. Quisemos, então, criar um espaço em que as pessoas se sentissem realmente à vontade para criar, para errar e em que o olhar - não o só nosso, como o dos colegas, os outros participantes - fosse essencialmente de procura por coisas positivas, mais do que negativas, e multiplicar esses momentos positivos, em vez de multiplicar o olhar destrutivo.

Claro, há uma crítica que é construtiva, mas não é a essa que me refiro. Refiro-me a uma crítica destrutiva que muitas vezes se encontra na pedagogia do teatro. Pelo menos era o que nos parecia na altura em que criámos o projecto, que foi depois evoluindo e criando a sua própria identidade, relacionada também com as pessoas que nos foram procurando; que foram muitas ao longo dos anos em que decorreu o projecto que agora está adormecido, mas que, com certeza, há-de regressar um dia, ainda que reformulado; porque ao fim de um certo tempo também sentimos necessidade de o reformular, para não cair nas velhas fórmulas.

0 programa Zonas foi sobre muitas coisas: tinhamos o um, o dois e o três - um em cada ano. Trabalhávamos sobre autores contemporâneos, às vezes, outras vezes trabalhávamos sobre autobiografia e imagens ou sobre palavras e escrita. Tantas coisas... É que cada Zona foi realmente única, nunca repetimos a mesma Zona. Os programas nunca foram iguais, foram feitos expressamente para aquelas pessoas e dependiam de quem nos procurava. Fizemos, por exemplo, uma Zona que foi memorável, em 


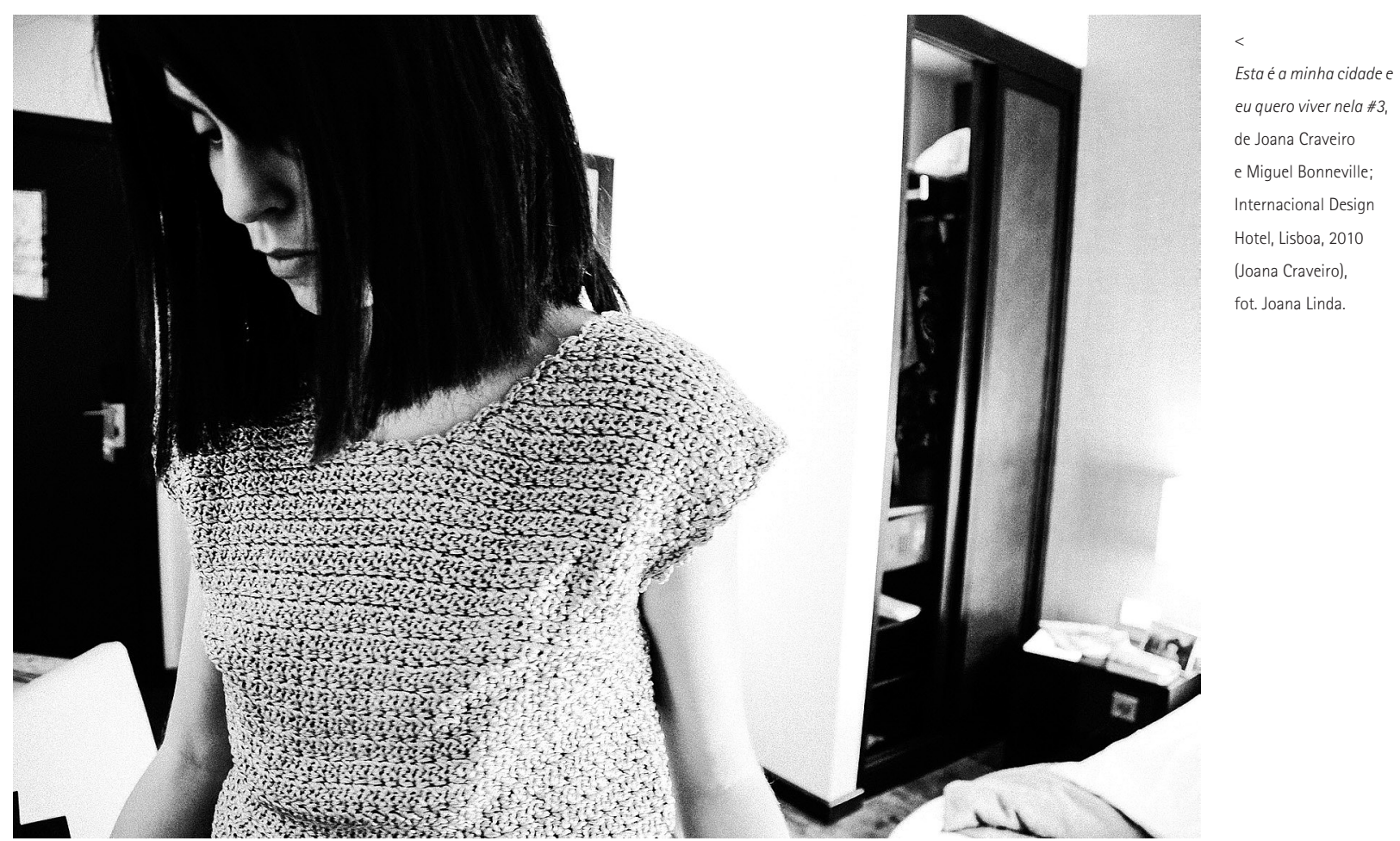

que trabalhámos a partir de autores de contos americanos em que os participantes encenaram o seu próprio conto. Trabalhámos com contos de Charles Bukowski, de Flannery O'Connor, de William Saroyan e foi realmente incrivel o trabalho que os participantes fizeram na altura.

As apresentações do programa Zonas eram sempre autênticos acontecimentos irrepetíveis, em que havia comida, convivialidade e essa ideia de comunidade. Chegámos a fazer apresentações de seis horas, em que as pessoas vinham, entravam, saíam e gerava-se ali uma comunidade, um interesse e um respeito em torno da criação. Acho que o programa Zonas cumpriu uma função importante e fico muito feliz quando vejo que os participantes, hoje em dia, fazem criações ou continuam o seu trabalho e a sua pesquisa. Muitos deles não estavam sequer ligados ao teatro e encontraram ali um espaço de criação, descobriram-se a si próprios como criadores.

Faria algum sentido, para o TdV, a edição dos vossos textos ou é uma ideia completamente disparatada? Não, não é disparatado. Nós gostávamos muito. Bom, não conseguimos fazer tudo aquilo que gostaríamos de fazer, porque realmente é muito difícil ao nível do tempo e somos uma companhia que vai crescendo, como costumamos dizer, mas a estrutura não cresce. Então continuamos a ser sempre os mesmos a fazer as mesmas coisas, mas o trabalho aumentou imenso nestes doze anos. Adorariamos editar os textos, mas nunca conseguimos arranjar apoio para os editar. Já tentámos editar, mas não tínhamos os meios financeiros, e há até a história curiosa de termos tentado editar o primeiro texto mas termos recebido uma fria carta que falava de "critérios editoriais selectivos para a edição de textos teatrais". Obviamente, a nossa escrita não se enquadrava nesses critérios! Conseguimos fazer a edição do nosso livro, que já foi uma tarefa monumental a que nos propusemos e conseguimos cumprir. Temos alguns projectos editoriais para este próximo biénio, para o qual soubemos que foi renovado o nosso apoio, mas também muitos deles não serão possiveis de concretizar com o dinheiro que nos foi atribuido. De modo que, sim, temos todo o interesse em editar. Temos um projecto de edição da Carta-oceano (2007), com a Maria Gil, do Teatro do Silêncio, e com a editora dela. Só que o trabalho de edição dos nossos textos coloca questões que têm a ver com a recuperação dos materiais, que muitas vezes não estão fixos, não estão registados do ponto de vista da escrita, estão documentados em vídeo e isso implica uma transcrição porque o texto final não está fiel àquilo que depois realmente aconteceu. Portanto, a edição colocanos todos esses problemas, os quais, muitas vezes, nós não temos o tempo nem os meios financeiros para resolver.

Não sei se é possível identificar fases, digamos assim, no trabalho do TdV.

Fases?... É possivel dizer que no princípio, nas três primeiras peças, trabalhámos de forma mais "normal". Na primeira, o texto já estava escrito à partida, antes de começarmos a ensaiar, o que implica uma forma de trabalhar completamente diferente. 0 segundo texto estava quase pronto à partida e foi escrito, também, durante o processo, mas não como os outros textos são escritos agora, que decorrem daquilo que acontece na sala de ensaio. Portanto, foi escrito com a ideia ainda de personagem, por exemplo, mais do que persona, algo que temos explorado mais, ultimamente. Há trabalhos que tiveram essa forma de funcionamento que eu descrevi agora, mas que não quero apelidar de convencional, porque acho uma palavra muito redutora. Nem sei bem o que isso quer dizer. Já houve alturas em que a usei de uma forma mais frequente e com mais certezas, mas hoje em dia questiono-me bastante em relação a essa palavra.

Depois, acho que há trabalhos de charneira, que são marcos. Como o Exaustos (2005), por exemplo, que é um 


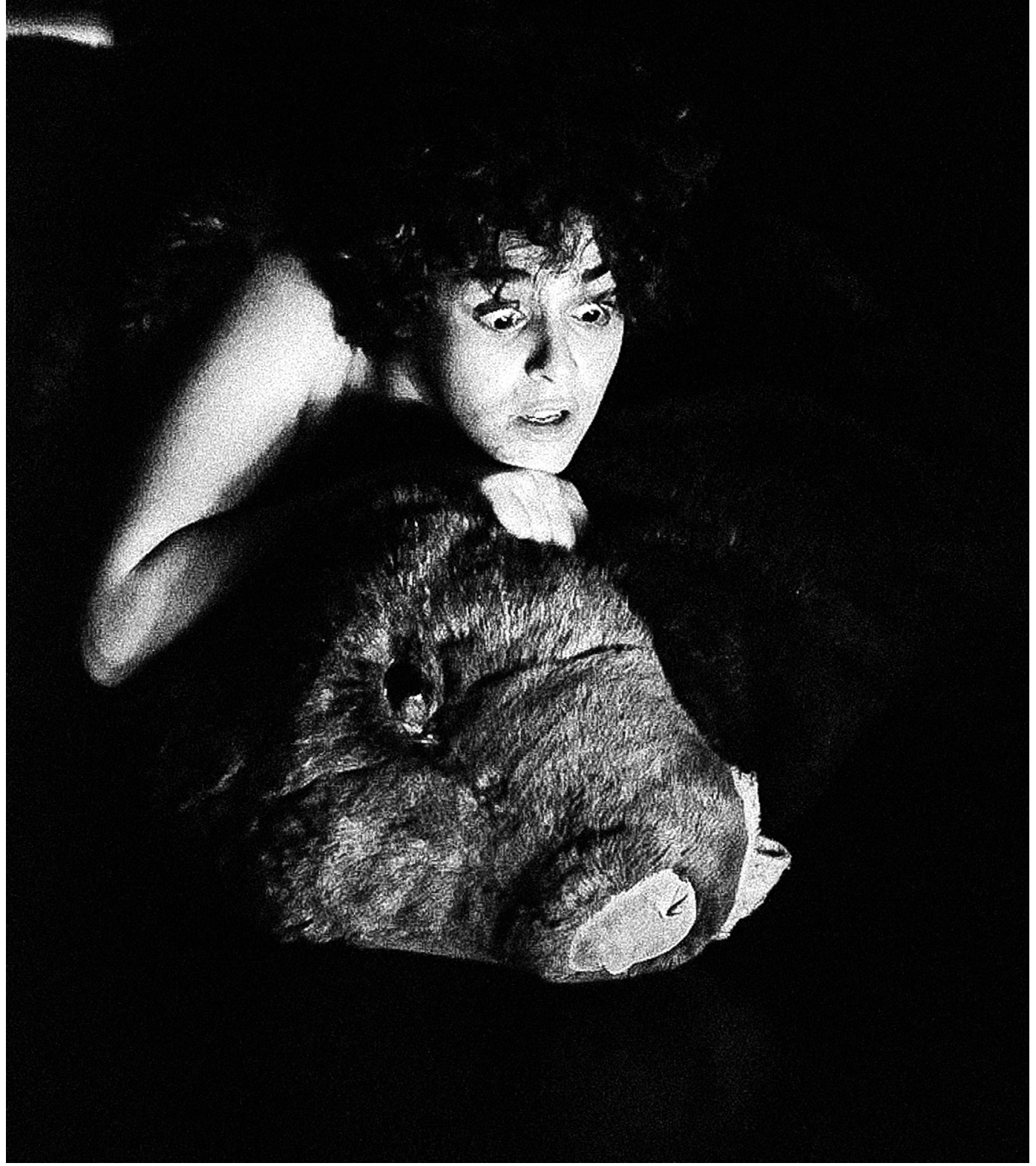

trabalho que mudou muitas das formas de funcionar da companhia, seja porque aí pela primeira vez, verdadeiramente, trabalhámos a fragmentação da dramaturgia, por exemplo, da não-linearidade, apesar de eu achar que nunca escrevi de forma linear. Nunca escrevemos de forma linear, mas nas três primeiras peças e mesmo no Cinzento (2003) - peça que fizemos entre Glasgow e Portugal - havia, de certa forma, a ideia de contar uma história, mesmo que fosse mais do que uma. Depois no Exaustos, não, isso é quebrado completamente e acho que inaugura mesmo uma nova forma de fazer em que cada fragmento vale por si e em que há uma grande experimentação ao nível da dramaturgia, mas também ao nível cénico e dos espaços - seja quando o fizemos no 3rceiro Andar no Chiado, que é um espaço que já nem sequer existe; deve estar em ruínas ali em frente ao antigo edifício da PIDE (este último, hoje um condomínio de luxo); seja quando o fizemos no Hospital Júlio de Matos, também, em que as pessoas entravam pela cave e vinham por umas salas esconsas e com um chão de terra batida. É possível identificar algo nesse projecto, mas não sei se Ihes chamaria fases. Acho é que 
cada projecto tem realmente uma identidade muito própria e se calhar, para mim, o tríptico Exaustos, Carta-oceano, Ilhas tem-na ao nivel das metodologias e da apresentação cénica. E depois as peças relacionadas com a literatura também têm evidentemente características próprias que as juntam. 0 Esta é a minha cidade... é um projecto completamente diferente, mas também tem a sua identidade, apesar das diferentes apresentações.

Só que eu não acho que isso corresponda a fases temporais, acho que isso corresponde antes a fases de criação que podem ser constituídas por duas peças que têm lugar num determinado ano e três anos depois pode haver uma peça que tem uma ligação com essas duas.

Claro que pode haver um estudioso que veja e leia as coisas e identifique fases. Eu não tenho essa percepção quando estou a criar e não penso dessa forma. Nem acho que nós pensemos dessa forma. Talvez agora, por exemplo, estejamos mais preocupados, desde o biénio anterior, em falar sobre a situação política em Portugal, mas não sei se isso corresponde a uma fase. Mais que isso, corresponde àquilo que nos parecem ser as urgências do momento e às quais o teatro deve dar uma resposta.

\section{De todo o trabalho que tem feito com o TdV, qual a} criação, que mais a marcou?

Não sei bem se é a que mais me marcou. A minha criação preferida é a Carta-oceano, mas acho que é uma relação afectiva. Como disse acho que o Exaustos, a Carta-oceano e o Ilhas são criações que levam o TdV numa direcção que se aproxima mais do que fazemos hoje e que se aproxima mais daquilo que queremos fazer ou que eu gostava de ter como funcionamento da companhia. Seja a nível do processo, seja ao nivel dramatúrgico e da implementação cénica das ideias. Nesse sentido, esse tríptico é muito importante.

Exaustos é uma peça, de certo modo, radical. Hoje em dia, quando vejo o vídeo, penso que se calhar não faria agora aquilo da mesma maneira, mas na altura foi realmente radical e importante. Um radicalismo perante nós próprios: não estou a dizer que foi um radicalismo em relação ao que se fazia aqui ou lá fora. Não estou a pensar dessa forma transversal, estou mesmo a pensar na relação com o nosso processo de trabalho. Foi muito importante e foi muito marcante. E a Carta-oceano, foi uma espécie de continuação disso, bem como uma das peças que eu gostei mais de fazer, como performer, e que gostei mais de ver, cenicamente. Sim, elegeria essa, acho eu.

Alguma vez pôs em cena um espectáculo que achasse que precisava de mais tempo para ser apresentado ou

\section{sempre apresentou os espectáculos exactamente como} queria?

Sempre apresentei os espectáculos exactamente como queria. Sempre. Mas acho que o tempo é uma questão grave e ao mesmo tempo premente para os fazedores teatrais, porque temos cada vez menos tempo. Penso que nos deixámos enredar e enganar por um sistema que nos obriga a produzir mais em menos tempo. E criámos formas - não sei dos meus colegas de outras companhias e projectos, mas imagino que eles tanto quanto eu - fomos criando formas de nos adaptar a esse constrangimento que nos fez reformular as nossas metodologias de trabalho. Neste momento, no TdV, conseguimos criar peças em duas semanas que estão bem para apresentar, por isso não tenho aquela sensação de necessitar de mais tempo, porque eu trabalho com aquilo que tenho e não com idealizações que não têm tradução prática. Nós trabalhamos sempre no constrangimento: somos uma companhia que nunca teve facilidades. Teve que lutar e labutar por tudo o que tem, e que é pouco. Portanto, não crio idealizações, nem fantasias com coisas que não tenho. Agora, claro, acho que somos vitimas de um sistema que nos obriga a produzir mais em menos tempo e a não fazer a pesquisa da forma que poderiamos se tivéssemos outro tempo.

Eu tenho como premissa no TdV termos sempre os espectáculos prontos uma semana antes de estrearem. Com as coisas que temos, sem trabalhar em fantasia. Eu sempre estreei as coisas como eu queria, dentro do tempo que eu queria, mas sempre com essa premissa de querer ter as coisas prontas uma semana antes, porque quero que as pessoas desfrutem, que não estejam em stress nem a pensar que vão estrear e não está pronto. Já tive muitas dificuldades, e agora, no Paredes de vidro, senti dificuldade em cumprir essa minha própria meta. Via os dias a passar e muitos problemas a surgirem - técnicos ou outros e pensei que talvez não conseguisse ter o espectáculo pronto tão cedo quanto queria. Talvez se tivesse mais uma semana poderia ensaiar melhor certas coisas, mas depois não, correu tudo como eu pensava (e desejava).

Mas acho que a questão não é bem essa, pelo menos para mim. Creio que nós todos, criadores, fomos realmente encontrando formas de contornar essa questão do constrangimento [do tempo] e não sei se isso é bom. Coloco-me mais essa questão do que a outra que colocou sobre o que eu faria caso tivesse mais tempo. Se calhar fazia um outro tipo de teatro, mas pronto, essa não é a realidade. Agora, a questão é: porque é que me habituei $a$ isso? E de que forma é que sou conivente e cúmplice com uma situação com a qual não concordo. Acho que é isso que nós todos temos de rever. 


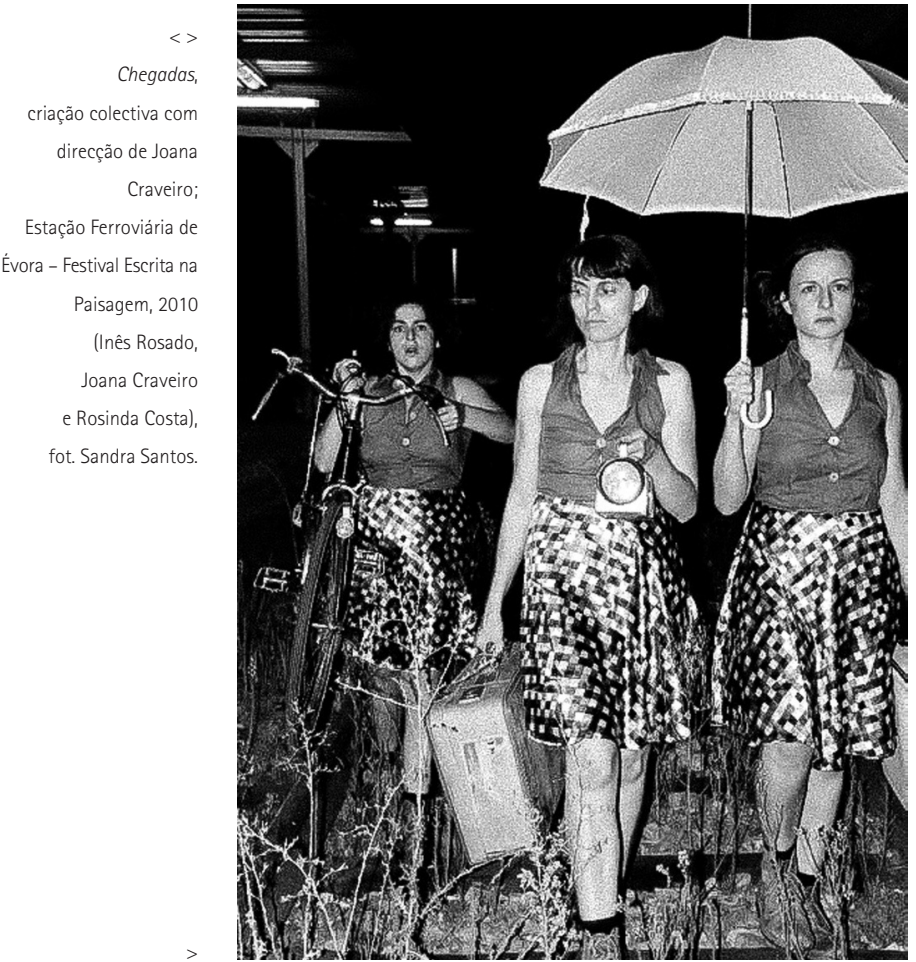

Chegadas,

criação colectiva com

direcção de Joana

Craveiro:

Liberdade Provisória,

Lisboa, 2011

(> Joana Craveiro

$\checkmark$ Inês Rosado

e Rosinda Costa)

fot. Filipe Dâmaso da Silva.

Nós recebemos sempre metade do dinheiro que pedimos, ou tivemos sempre um corte grande em relação ao que pediamos, mas fazíamos questão de fazer todas as coisas que nos tínhamos proposto, e isso está errado. 0 organismo que nos subsidia deveria saber, ou compreender que, à partida, se nos dão metade do dinheiro que nós pedimos (e cujo pedido justificámos) não vamos ter condições para fazer aquilo que nos propúnhamos fazer. Há aqui uma espécie de paradoxo, porque eles, realmente, valorizaram-nos por um projecto que depois, na prática, não vai poder acontecer. Só que todas as companhias, todos nós, nesta nossa ânsia ética - e acho que muito bem, porque temos de ter princípios e de os cumprir resolviamos sempre fazer tudo, mas com metade dos meios. E penso que isso foi um erro. Tem sido um erro. E espero que agora, com este resultado, todos os projectos e companhias reflictam. Com certeza que o estão a fazer, nós também estamos a reflectir sobre o que podemos ou não podemos fazer para quebrar esse sistema de fazer espectáculos em duas semanas ou três semanas.

Quando estudei na Escócia, achava um absurdo fazerse peças em três semanas e depois cheguei a Portugal e dei por mim a fazer a mesma coisa ao fim de uns anos. Quando comecei a fazer teatro os processos prolongavamse por quatro meses. Quando havia um mês ou mês e meio já nos parecia pouco tempo, todos se queixavam. E hoje em dia parecemos todos uma fábrica de espectáculos, quer dizer, para quê? Porquê? Para quem?

Tudo aquilo em que começaram a trabalhar viu a luz do dia ou houve coisas que se perderam e ficaram na gaveta?

Há sempre algo que se perde durante os processos, mas assim algo que tenhamos começado e que não tivesse acontecido como projecto, até hoje não. Todos eles se concretizaram ou sob a forma de espectáculo ou de apresentação informal. Já fizemos muitas apresentações
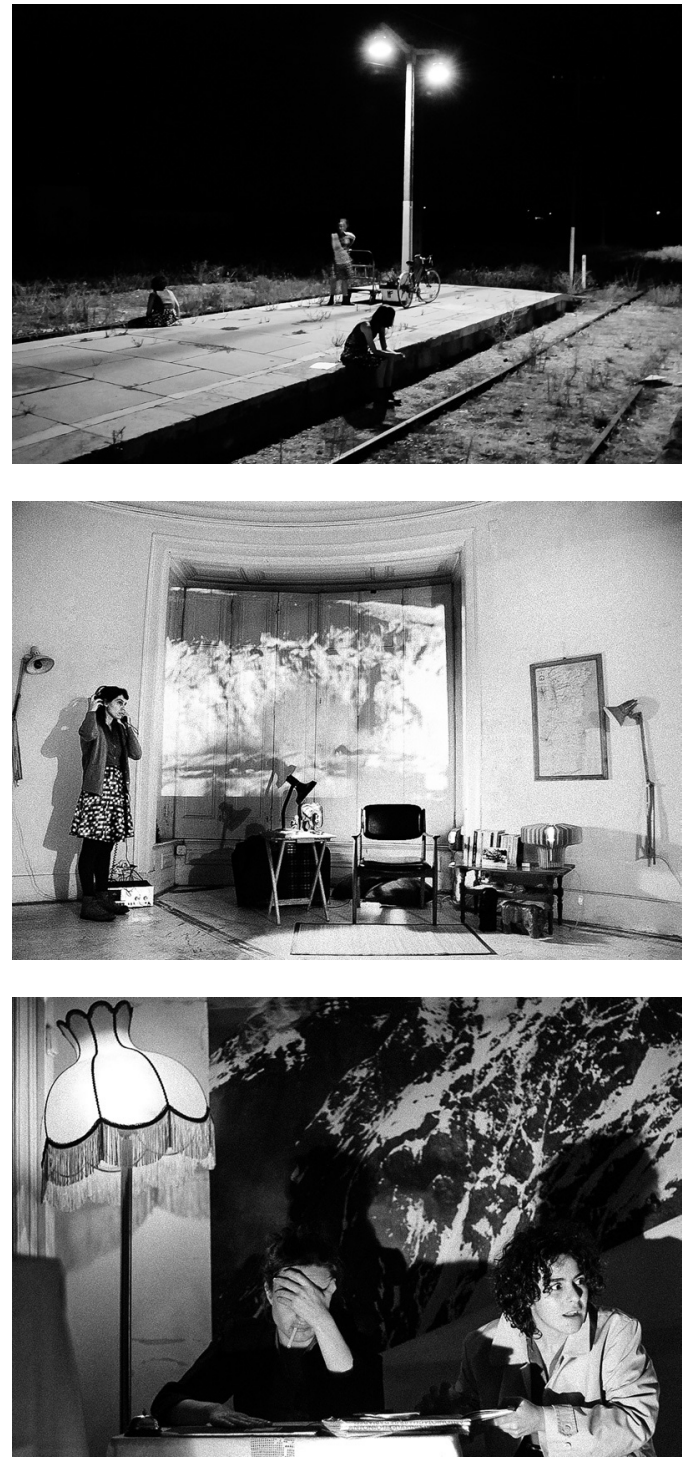

no [Festival] Escrita na Paisagem, por exemplo, onde faziamos sempre uma apresentação antes da estreia e que acabava por ser única.

Recordo-me, por exemplo, também, de uma peça que fizemos que era a 3 Elvira3 que teve só uma apresentação ou duas no Brasil, em São Paulo, e outra numa escola aqui. Esse projecto nunca teve continuidade. Foi a única peça que acho que não se fez tanto quanto se poderia te feito; não se investiu tanto quanto se poderia ter investido para ela acontecer. Foi uma altura muito complicada: não éramos subsidiados, fazíamos aquilo com o resto do nosso tempo e ninguém recebia nada, por isso será talvez normal que não se tenha conseguido... E depois há a tristeza de nunca termos conseguido fazer o Lugar nenhum (2002) em Lisboa - só conseguimos em Faro, Vila Velha de Ródão e São Paulo..

Mas tudo até hoje que nós quisemos estrear, estreámos, mesmo que tenha sido só uma apresentação como esses espectáculos - ou duas ou três. Agora, há muita coisa durante os processos de trabalho que fica pelo caminho, isso é verdade, e que não entra no espectáculo final.

No livro há uma passagem em que se pode ler: "Alguns dentre nós são acérrimos defensores do arquivo, outros 

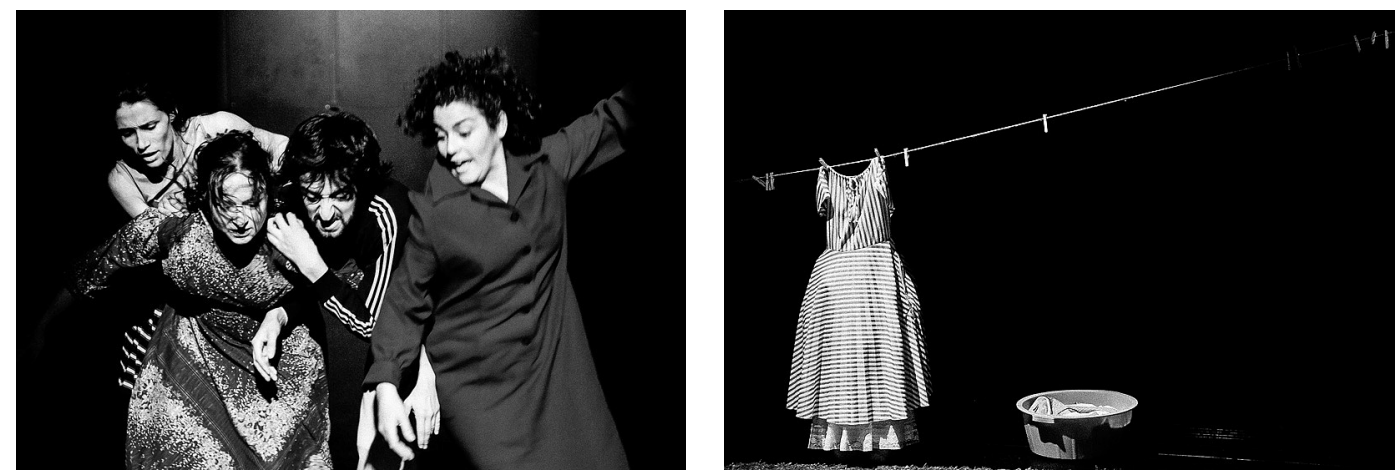

$<>$

Tropeçar,

texto e direcção de

Joana Craveiro;

CCB, Lisboa, 2011

(<Inês Rosado,

Lara Portela,

Raimundo Cosme,

e Rosinda Costa;

$>$ Inês Rosado),

fot. João Paulo Serafim da ausência dele". De que lado se situa a Joana Craveiro e por que motivo o defender e por que motivo não o defender?

Eu sou uma respigadora. Se falar com alguém sobre mim irá saber. Eu guardo tudo o que posso que seja antigo. E sou uma acérrima defensora do tal arquivo. Sou eu. Os meus colegas, muitas vezes, querem deitar metade do nosso espólio fora. Depois até deitam nas minhas costas e quando eu descubro fico irritada porque atiraram fora coisas que era suposto termos guardado...

Sobre isso do arquivo: acabo de vir de uma conferência sobre arquivo, documentos e essas coisas todas. Teria muito para dizer sobre isso. Estou a fazer um doutoramento sobre essa questão da transmissão da memória e do arquivo ou do reportório da memória.

Razões para defender, ou não defender, não sei. São coisas pessoais. Eu sou muito apegada, ou tenho uma forma de me apegar a certos objectos que deve estar relacionada com querer preservar as coisas contra 0 esquecimento, não sei. Não tenho uma interpretação psicológica disso. E alguns dos meus colegas são contra isso. São contra ter e manter o objecto, às vezes até contra ter o objecto em cena, preferiam não o ter, e por isso essa frase que citou. Somos um colectivo que tem essas diferentes visões e como também nunca temos espaço ou tivemos de deixar vários espaços várias vezes, isso cria outros problemas, como onde colocar as coisas quando deixamos um espaço onde estão armazenadas. A relação com o arquivo ou com o guardar certos objectos ou memórias tem a ver também com esses constrangimentos. Nós já passámos tantas vezes por essa questão, que alguns - de nós - realmente acham que é um disparate guardar e que mais valia deitar tudo fora. Eu acho que não, que temos de lutar contra isso, contra essa circunstância, contra isso que nos obriga também a essa destruição permanente da memória.

Não acho que as circunstâncias devam ditar o arquivamento ou não da nossa memória, acho que devíamos conseguir lutar contra, mais uma vez, o sistema que nos condiciona. Tal como com a questão do tempo, temos aqui a questão do espaço, que está ligada ao dinheiro, claro. Isto tudo está sempre ligado à questão financeira, que até determina o que se pode ou não guardar; o que se pode ou não arquivar. E eu quero lutar contra isso tudo.

Portanto, poder-se-á dizer que o livro é produto desse esforço?

Sim, o livro é produto de um esforço monumental de recuperação de coisas e é espelho também desse conflito dentro da companhia, entre essas visões diferentes, sobre o que se deve ou não guardar; sobre o que se deve ou não registar. 0 livro é fruto dessa tensão, desse debate e desse esforço. E quem compilou o livro foi quem teve 0 maior trabalho de nós todos - a Catarina Vasconcelos, uma incrivel designer gráfica - porque, de facto, ela não conseguia perceber como é que nós éramos tão desorganizados [risos]. E ela própria teve de repescar essas memórias. Portanto, o livro acaba por ser, também, a selecção que ela faz de um acervo completamente caótico e inclassificável e inclassificado ao qual ela depois dá forma nesse livro. Esse trabalho é um mérito essencialmente dela e da sua perseverança contra as nossas próprias resistências, debates, dificuldades para nos conseguirmos organizar.

Por ocasião do décimo aniversário da companhia receberam uma menção especial da Associação Portuguesa de Críticos de Teatro (APCT). Como é que receberam esse reconhecimento?

Recebemos bem! [risos]. Ficámos contentes. Não estávamos à espera. Nunca tínhamos sido mencionados pela APCT, nem sabiamos se eles nos conheciam. Tirando um ou outro crítico, que sabiamos que acompanhava o nosso trabalho, não sabíamos que a entidade em si estava consciente do nosso percurso. Portanto, nesse sentido, tomámos como um reconhecimento, que ainda por cima era pelos dez anos de trabalho, que nos deixou contentes. Não vou dizer que nos pareceu justo, porque isso parece-me um bocado presunçoso. Não sei se é merecido, se não é merecido, mas fiquei contente. Ficámos contentes que tivessem reconhecido que, realmente, durante dez anos tínhamos estado a trabalhar num percurso que a nós nos parece coerente. Pelo menos sempre tentámos que fosse, na nossa pesquisa, na nossa busca. Também sabemos que somos um bocado off. Muitas vezes até off espacialmente, como quando estivemos no Júlio de Matos, por exemplo; era um sítio onde o público não ia, porque é um bocado fora dos circuitos normais da cidade e tem uma carga simbólica bastante forte que afasta as pessoas, o que foi uma pena, porque foi onde fizemos peças muito interessantes; inovadoras, mesmo, no nosso percurso. Portanto, nós que temos tido esse percurso um pouco à margem, de repente sermos reconhecidos... Gostei muito e gostei do texto que escreveram e gostei daquilo pelo qual nos reconheceram. Uma forma de arte atenta a todos os cidadãos e ao mundo em que vivemos, pareceu-me uma descrição certa, sim.

E nesse percurso de dez anos o TdV criou um público próprio ou nem por isso? 

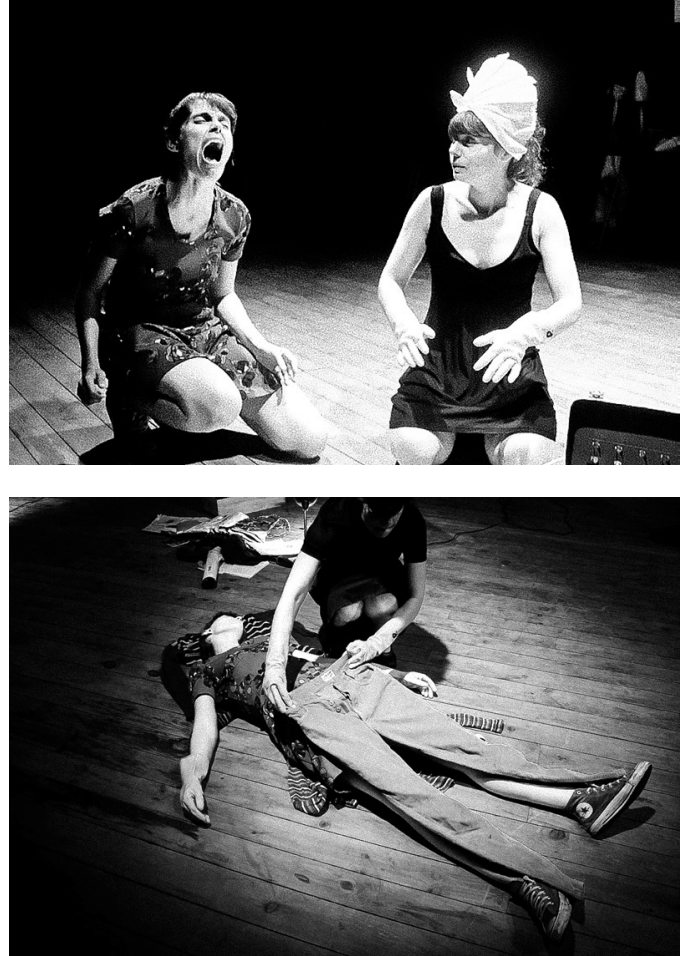

Agora já tinham passado

dez anos e nem sombra

deles em lado algum criação colectiva com

direcção de

Joana Craveiro

Negócio/ ZDB, Lisboa,

2011

(^ Joana Craveir

e Tânia Guerreiro,

revisitação de uma cena

de Carta-oceano

$<$ Joana Craveiro

e Tânia Guerreiro,

revisitação de uma cen

de Exaustos:

v Joana Craveiro,

revisitação de uma cena

de Carta-oceano

$>$ Joana Craveiro

e Pedro Caeiro)

fot Helena Colaço Salazar.

Acho que criámos um público, sim. Não conheço muito bem todas as pessoas, mas acho que criámos sobretudo uma comunidade, que era o nosso objectivo. Isso tem a ver com o programa Zonas, que movimentou muitas pessoas, tanto os participantes quanto os que vinham assistir às apresentações, e essas pessoas, de certa forma, ficaram o nosso público. Seja por pensadores ou outras pessoas que se começaram a interessar pelo projecto da companhia, e que começaram também a ver os espectáculos E acho que criámos um público, não quero estar enganada ou iludida, mas eu sinto que sim. Que criámos uma comunidade de pessoas que segue o nosso trabalho.

Como se ligam as palestras da FNAC aos espectáculos? São actividades complementares que existem para cada um dos projectos. Nós pensamos sempre numa série de actividades complementares, para cada um deles. E as palestras são momentos pensados como partilha do processo de trabalho, mas ao mesmo tempo também partilha de questões periféricas ao trabalho e com ele relacionadas. Para essas palestras especificas da FNAC convidamos pessoas que não têm necessariamente a ver com teatro. Por exemplo, para o Esta é a minha cidade. convidámos urbanistas - ou vereadores da câmara - para falarem sobre a cidade. Pareceu-nos importante ter outros olhares. Já tivemos psicólogos e um ornitólogo, uma vez. quando foi do Pássaro azul. Convidámo-lo para falar sobre uma espécie que é um pássaro azul da India.

As palestras têm tudo e não têm nada a ver com a peça que estamos a fazer. Ou seja, tem mais a ver com o projecto do que só com a peça. E a ideia é sempre captar um novo público, por isso costumamos fazê-las na FNAC e ao mesmo tempo criar uma apresentação que é performativa e que também tem uma identidade por si só. Há pessoas que nunca chegam a ver o espectáculo, mas vêem aquilo. E aquilo é indicador de qualquer coisa e reflexo do nosso trabalho.
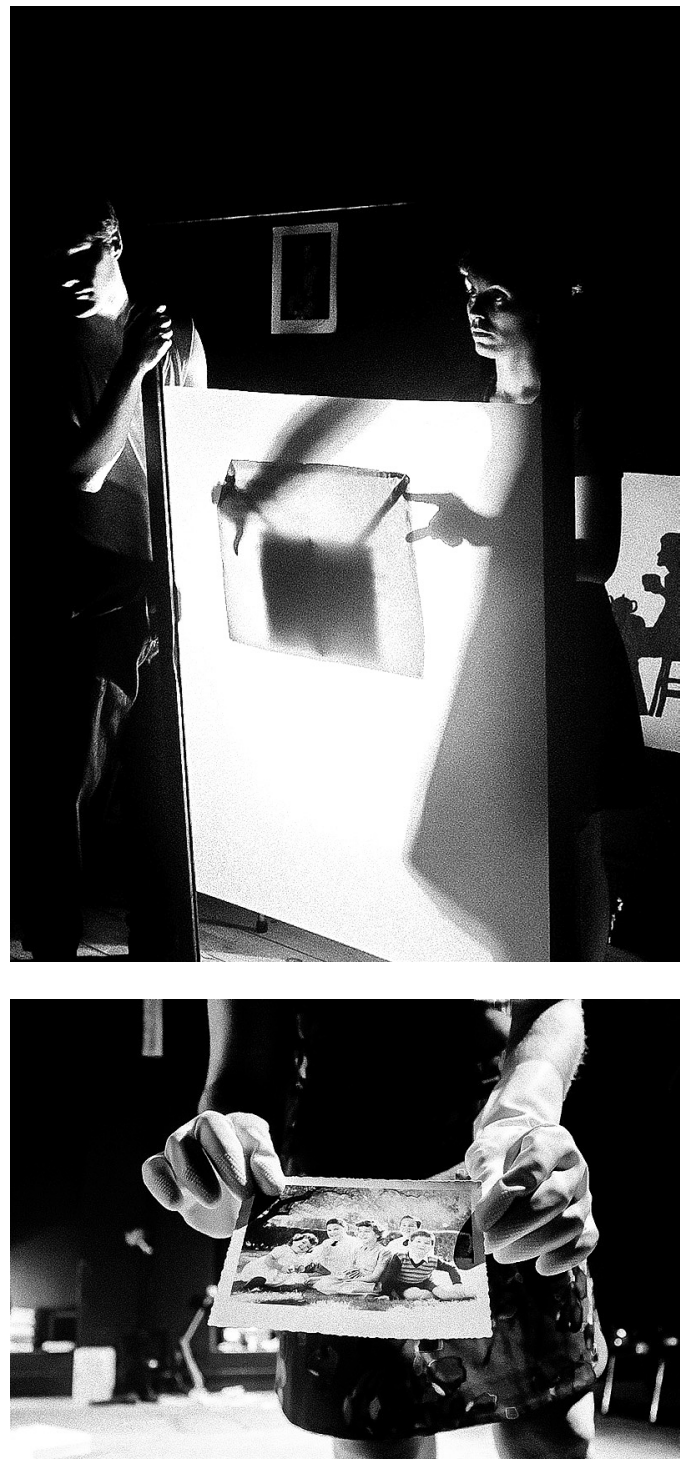

$0 \mathrm{TdV}$ tem marcado presença em eventos como o Festival Escrita na Paisagem, o Citemor - embora tenha visto recentemente uma entrevista em que afirma que foi uma chegada demorada ao Citemor mas também estiveram no Festival de Curitiba. Como foi essa experiência?

0 Festival de Curitiba foi... foi bom. Para nós é dificil separar o Festival de Curitiba de São Paulo. Nós tínhamos acabado de apresentar as três peças [a trilogia Monstro (2012/2013)] em São Paulo. Foi uma experiência muito diferente de qualquer festival português. Desde 2006 que temos uma relação com o Festival Escrita na Paisagem e é outra coisa. Acho que os festivais de teatro em Portugal - pelo menos aqueles em que participámos - têm uma relação com a criação, com a residência artística e com as populações. É muito diferente de um festival com a dimensão do de Curitiba, porque tem a dimensão do Festival de Teatro de Edimburgo, o fringe, portanto são trezentos e tal espectáculos. E a experiência foi muito boa no sentido em que é sempre muito bom apresentar o ciclo de peças referentes ao Monstro em diferentes contextos, nomeadamente internacionais, onde possamos estabelecer pontes entre aquilo sobre o qual falamos, que tem a ver com a situação politica em Portugal e na Europa, com os 

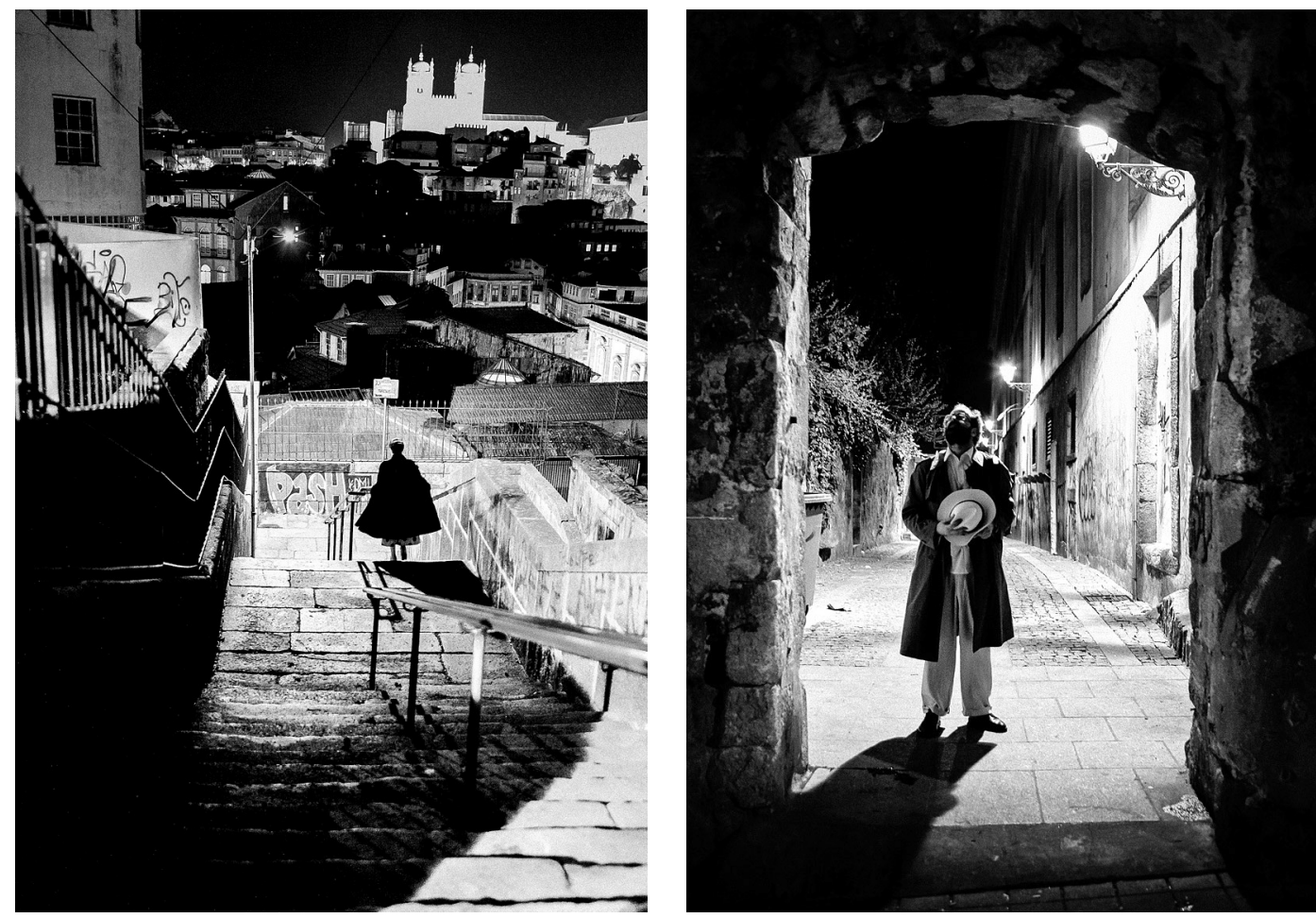

Esta é a minha cidade e

eu quero viver nela -

edição especial Porto,

criação colectiva com

direç̧ão de

Joana Craveiro;

espaço circundante ao

Mosteiro de São Bento da

Vitória, TNSJ, Porto, 2012

(<Tânia Guerreiro;

$>$ Gonçalo Alegria),

fot. João Tuna/ TNSJ.
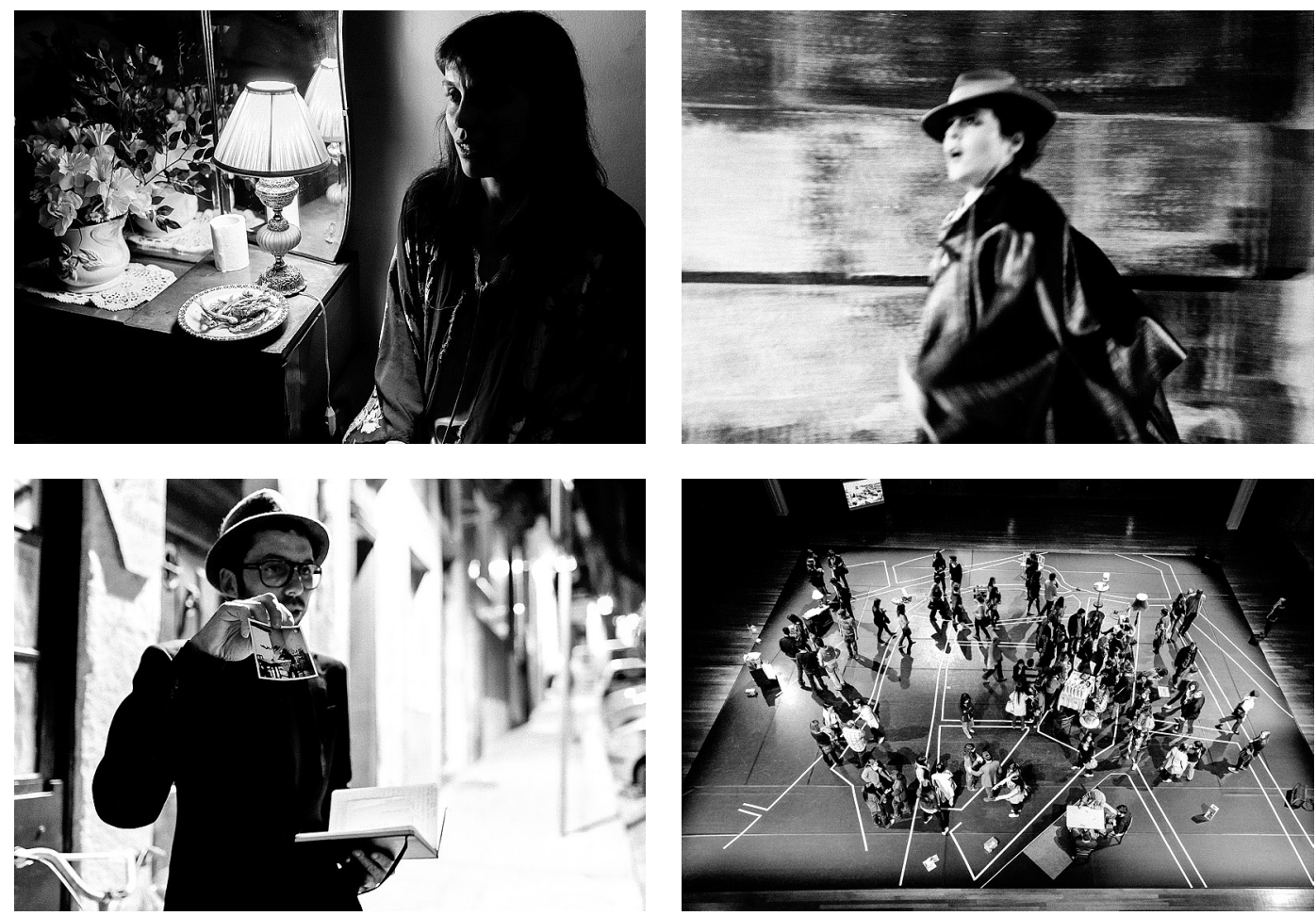

$<$ Victor Hugo Pontes.

$>$ cena final no Mosteiro SBV

sítios em que nós estamos: já fizemos em Madrid, agora em São Paulo e Curitiba, portanto há esse aspecto muito interessante das transversalidades e das relações que se podem encontrar com o sítio onde se está no momento a apresentar

Agora, claro, tem outras dificuldades, por exemplo, o número de espectadores. São dificuldades inerentes à própria apresentação em pouco tempo que um festival dessa natureza tem e que é diferente de festivais como o Citemor ou o Escrita na Paisagem, porque tem outras condições e outra dimensão: estamos a falar de 372 espectáculos. Mas foi muito interessante ver pessoas que disseram que entraram e lembraram-se do Vladimir Herzog, que foi um dos mártires da ditadura brasileira. Uma senhora disse que entrou no espaço e lembrou-se imediatamente dele, quando viu uma imagem que lá está de um estore com uma silhueta. Eu achei isso muito interessante, porque não pensei que alguém fizesse essa ligação logo à entrada do espectáculo, sem sequer ouvir de que se tratava. Também foi bom as pessoas quererem voltar para os dois espectáculos. Depois de verem o primeiro, quererem ver o segundo e fazerem todo aquele
$<$ Joana Craveiro.

$>$ Rosinda Costa. 


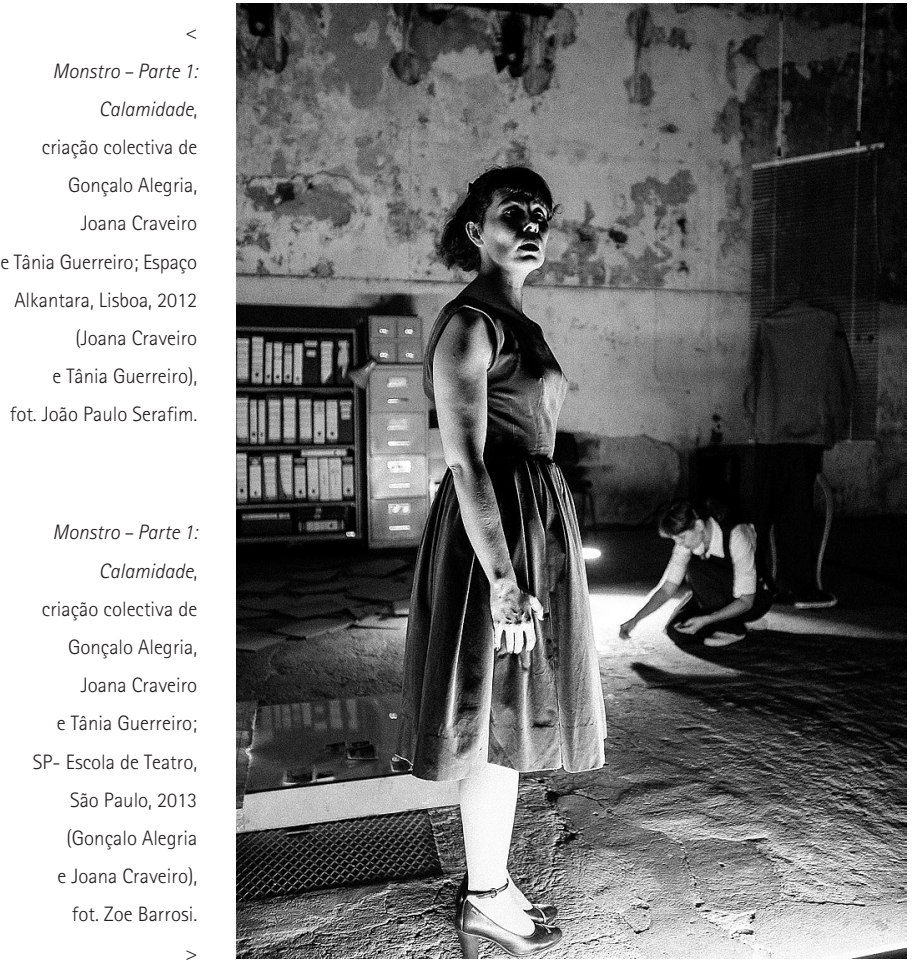

caminho para chegar àquela sala e ver o segundo, o Hecatombe, a meio do dia. Isso é extraordinário.

Foi também no Brasil, mas na Escola de Teatro de São Paulo, que estrearam a última parte do Monstro. Como foi recebido?

A recepção foi sempre óptima, tanto desse espectáculo como dos outros. Esse espectáculo teve co-direcção do Maurício Paroni de Castro, que é uma pessoa que tem a sua comunidade de seguidores em São Paulo, por isso, à partida, havia essa empatia e foi muito bem recebido, sobretudo por quem viu os outros dois, e encontravam ligações importantes entre eles.

0 terceiro espectáculo, nós assumimo-lo como uma espécie de laboratório. Foi construido em muito pouco tempo; lá está: os constrangimentos do tempo que o dinheiro cria. Ou a falta dele. E portanto, não o considero como um espectáculo acabado. Para mim, ainda é um processo, e foi nessa perspectiva que nós o apresentámos, mas a recepção foi muito boa. Com a lotação sempre esgotada. E as pessoas tinham muito interesse.

Portanto, muito provavelmente, o espectáculo a estrear cá, em Portugal, vai ser relativamente diferente do que foi apresentado no Brasil?

Sim, se retomarmos esse trabalho cá, sim.

Numa altura em que o que reina é corte cego, como é que isso tem impacto no TdV? Sofre constrangimentos financeiros muito grandes em relação ao passado? Como é que o TdV lida com isso?

Já falei um pouco sobre isso. Aquilo que estes cortes operam, quanto a mim, é uma destruição das estruturas, mais do que os projectos pontuais que as companhias possam fazer. Portanto, o que a companhia deixa de ser capaz de fazer é dar condições de trabalho às pessoas permanentes, que era o que deveria poder acontecer para

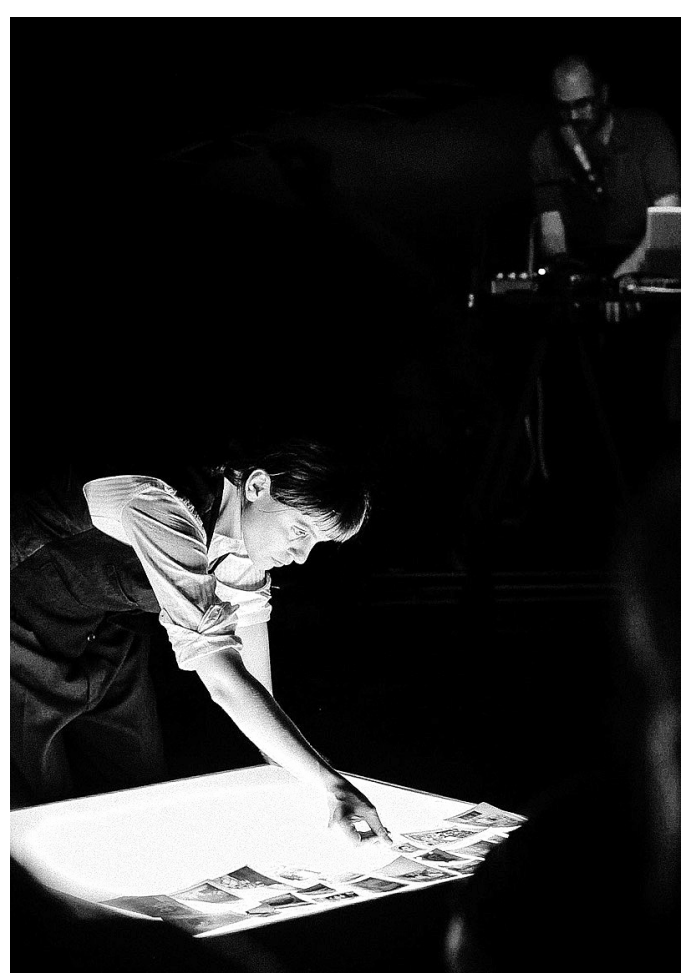

que as pessoas pudessem trabalhar para a companhia com a exclusividade possivel e pudessem dedicar-se a construí-la.

A companhia não serve só para fazer espectáculos, nem isso seria possível ou viável. Nós temos outras coisas que queremos fazer e desenvolver e elas têm de acontecer quando não se está a fazer espectáculos. À partida, quando se destrói uma estrutura do ponto de vista financeiro, destrói-se essa possibilidade. Logo, a companhia fica mais pobre do ponto de vista criativo. Não é apenas mais pobre do ponto de vista financeiro. Fica mais pobre do ponto de vista das ideias, do ponto de vista do desenvolvimento de novas metodologias, porque não há esse tempo, e não é quando se está num processo de trabalho - cujo tempo é cada vez mais curto - que se consegue desenvolver coisas inovadoras e fazer investigação para a própria companhia. Não se conseguem, pronto. Isso é completamente impossivel.

0 corte que nós sofremos, por exemplo, para estes próximos dois anos, impede-nos de realizar a maioria dos projectos que propusemos e pelos quais fomos subsidiados, o que acho que é aquele paradoxo de que falei aqui, extremamente interessante (estou a ser irónica), que realmente me faz pensar por que razão nos apoiaram, porque sabem que não vamos conseguir fazer exactamente aquilo que nos propusemos fazer, essa é a primeira coisa. Destrói a nossa estrutura, isso é a segunda coisa. Destró a possibilidade de manutenção de um espaço de trabalho por exemplo, o que acho dramático. Seja ao nivel de ensaios, seja poder fazer acolhimento a outros projectos, que é também uma das coisas que nós nos propúnhamos fazer e que não vamos conseguir realizar por causa disso.

0 júri deu o seu melhor com os constrangimentos que tinha, que eram muitos. Conseguiu, de certa forma, aumentar o número de projectos apoiados. Eram 30, passaram para 54, portanto isso também é mérito dele. E com certeza, fez o melhor que conseguiu com o pouco 


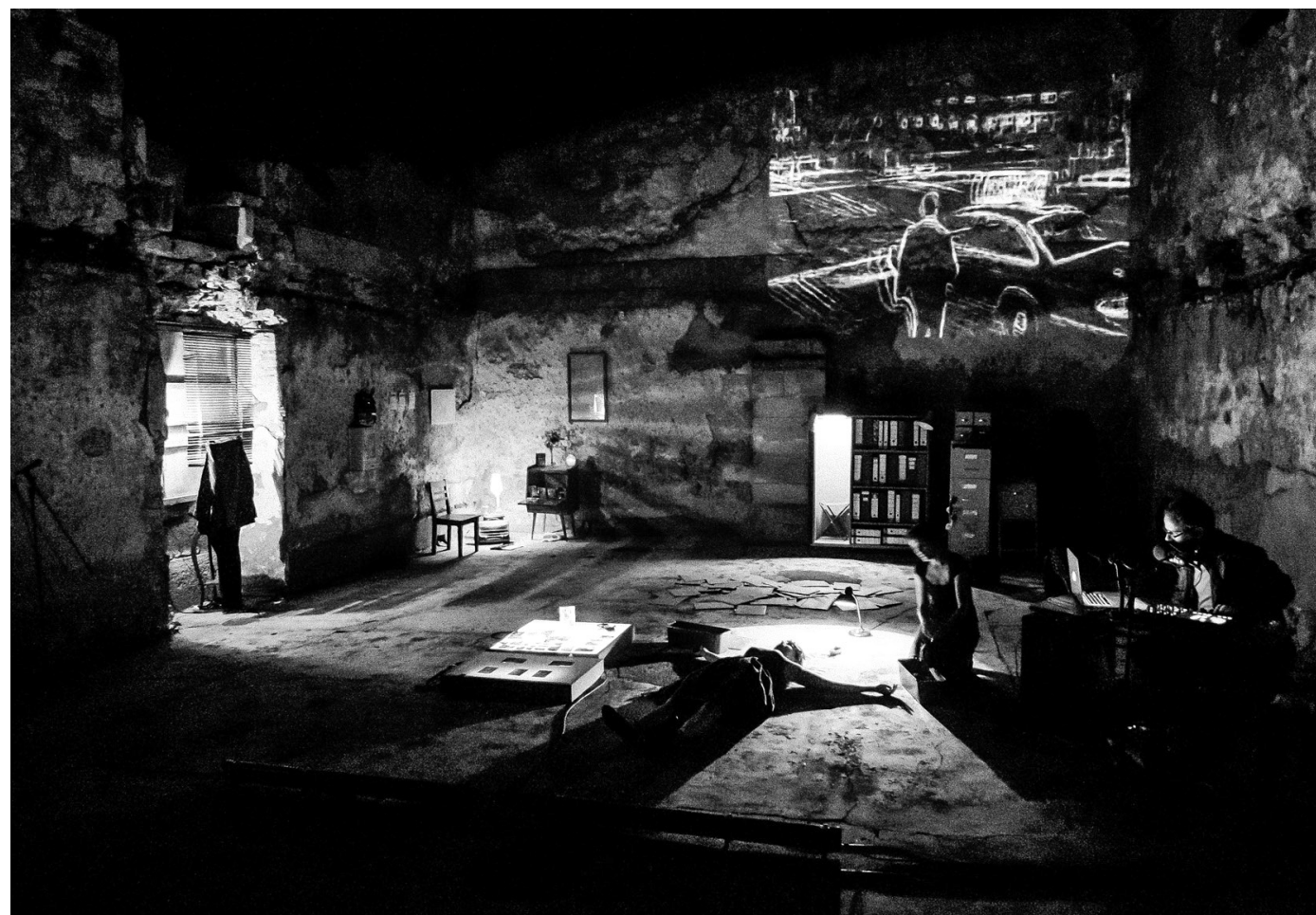

dinheiro que havia. Mas de facto, cortarem metade do que peço, não é o mesmo que cortarem 50 mil euros a uma companhia que recebe 400 mil. De facto não é a mesma coisa [risos].

Nesse sentido, sinto que as pequenas companhias acabam por ser vítimas de um sistema igualitário - ou supostamente igualitário entre todas - mas que não tem em conta as especificidades das companhias mais pequenas. Sem nenhum tipo de juízo de valor, porque o TdV não quer ser uma companhia que recebe esses valores de que estávamos a falar, porque não nos fazem falta. Mas fazianos falta aquilo que pedimos. Aliás, o nosso orçamento é elogiado pelo júri como sendo realista. E portanto, ao não nos dar o que pedimos e ao dar-nos metade, realmente, condiciona-nos em tudo: a programação, o funcionamento, a estrutura, e acho que, acima de tudo, condiciona o espaço de respiração e a possibilidade de pesquisa da companhia e da manutenção das actividades complementares, que é uma coisa pela qual somos muito valorizados. Leva-me a pensar que somos valorizados por algo que não vamos conseguir fazer. E isto faz-me reflectir muito sobre a continuidade e viabilização do projecto do ponto de vista financeiro, mas em principio não vamos desistir.

\section{E mecenato?}

Mas qual mecenato? [risos]. Mas que mecenato é que está interessado em investir no TdV? Isso é também uma ilusão.

\section{Mas por exemplo, a Casa Conveniente, apela à} contribuição do público.

Ah, sim. Mas não chamaria a isso mecenato. A Casa Conveniente tem esse sistema com o público, e para ela provavelmente funciona. Mas eu sinto que as pessoas não têm dinheiro para viver, por isso eu não Ihes vou pedir para sustentarem a companhia ou para a apoiarem. Não pensamos nessa estratégia como forma de angariação de fundos.
Lembro-me que quando começámos o TdV tínhamos muito a ilusão de que pudesse, um dia, existir um mecenato que nos apoiasse e, na altura, a primeira peça até foi feita com o dinheiro que certas empresas nos deram em regime de mecenato, mas acabou logo ao fim de um espectáculo. Nunca mais conseguimos retomar essa estratégia. Nem com a declaração de Manifesto Interesse Cultural, que era uma coisa que o ministério na altura dava e que nós pedíamos e permitia às empresas poderem deduzir "X" valor nos impostos.

Pelo que eu percebo, as empresas estão interessadas em patrocinar grandes teatros, e uma companhia como o TdV não atrai essa intenção. Depois, quanto ao público, não sinto que as pessoas possam pagar, sinceramente, neste momento, sequer os bilhetes. Acho que é mesmo uma luta que as pessoas empreendem para continuarem a ir ao teatro. Por isso acho que é dificil a angariação de outras fontes de financiamento. Claro, às vezes há instituições que apoiam, como a Fundação Calouste Gulbenkian, mas é realmente uma luta, o condicionamento financeiro.

\section{Muitos jovens acabam por procurar lá fora} oportunidades melhores. Alguma vez pensou nessa possibilidade?

Eu já andei muito por fora. Estudei na Alemanha, na Escócia, trabalhei lá, estudei em Chicago, e agora faço doutoramento em Londres. Não acho que seja solução. 0 TdV vai emigrar? Isso não faz sentido nenhum. Nós trabalhamos com textos em português, construimos todo um património e uma comunidade aqui, não faz muito sentido agarrar e ir viver para outro país. A companhia não sou eu sozinha, nunca poderia fazer uma coisa dessas.

Depois não acho que isso seja solução, também, para o pais. Sou contra isso. Sou contra o que isso significa, sobretudo do ponto de vista politico e social. Nós estamos a ser empurrados para esta situação que é um retrocesso 


\section{$<>$
$\vee$ \\ Monstro - Parte 2: \\ Hecatombe, direcção de \\ Mauricio Paroni de Castro; \\ ZDB, Lisboa, 2012 \\ < $<$ Tânia Guerreiro; \\ $>$ Joana craveiro; \\ $\checkmark$ Gonçalo Alegria \\ e Mauricio Paroni \\ de Castro),}

fot. João Paulo Serafim.
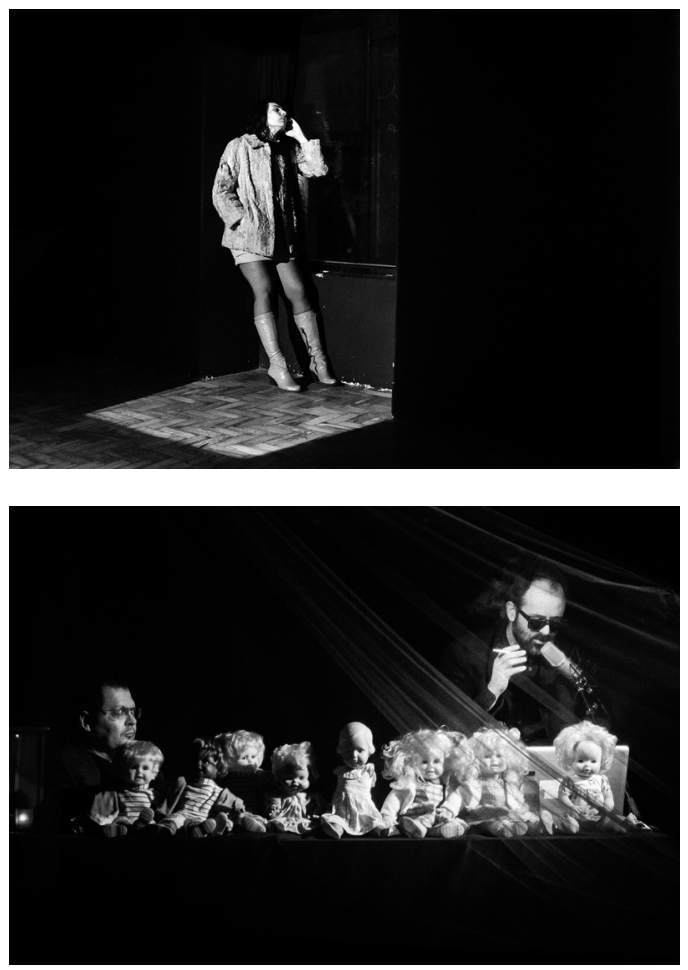

tão grande em relação à nossa história. Isso era a história de Portugal e de 48 anos de ditadura com a qual eu, de facto, não vou compactuar. Eu, pessoalmente, não vou. Vou lutar o quanto conseguir para não me ver nessa situação.

Em relação à companhia, então, está completamente fora de questão, porque o TdV não iria resistir noutro pais. Poderia torna-se noutra coisa, mas também é só quem não conhece as realidades de outros paises. Trabalhei em Inglaterra e Escócia e são tantas e tantas pessoas a trabalhar nesta área que também não me parece que seja muito fácil podermos sobreviver financeiramente. Claro, se falarmos sobre fazer outro tipo de trabalhos... Mas aí pergunto-me para quê, não é? Emigrar para situações às vezes de maior precariedade ou outro tipo de trabalhos que não têm nada a ver com aquilo em que nos formámos e para o qual estudámos e trabalhámos. Essa também não me parece ser uma situação que defenda. Sou mesmo contra isso. Agora, claro, compreendo que a situação do país seja extremamente complexa, nomeadamente para os jovens. Mas acho que se todos nós virarmos as costas e nos fomos embora... 0 que é que fica? 0 que é que acontece? Parece-me que isso não é solução e acho que temos de resistir e continuar. Não podemos simplesmente resignar-nos a este estado de coisas. Penso que, de certa forma, é compactuar com uma política que nos empurra para fora, por isso não devemos fazê-lo.

Em relação à década do $\mathrm{TdV}$ - agora um pouco mais - qual é o balanço que faz dela?

É positivo. Não desistimos, continuámos. Podiamos ter acabado várias vezes, fechado portas, tivemos muitos momentos cruciais em que poderia ter acabado, por falta disto ou daquilo ou por haver este ou aquele problema, mas continuámos. 0 balanço que faço é muito bom, sinto reconhecimento pelo nosso trabalho e respeito também. Sinto que começamos a fazer algumas coisas que queríamos fazer há muito tempo, como a

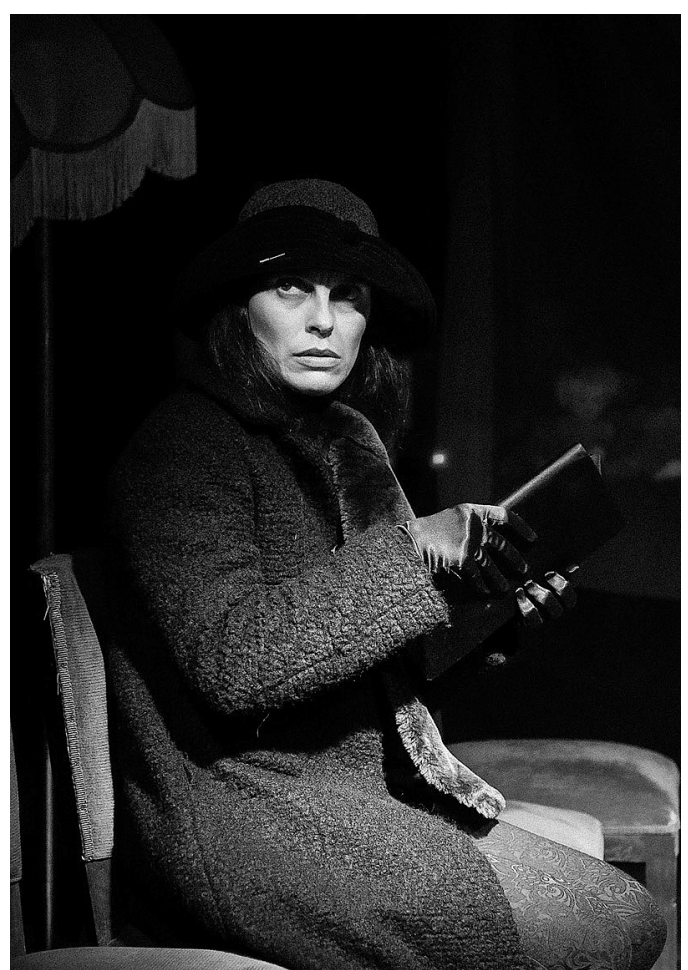

internacionalização e o estabelecer de pontes com outros criadores no estrangeiro e em Portugal. Sim, o balanço é positivo.

0 trabalho compensa, e acho que isso também é um axioma importante. 0 trabalho compensa e tem uma repercussão quando se investe e continua. Acho que não há facilidades na vida para ninguém. Nós, por exemplo, nunca tivemos facilidades, mas acredito que as coisas se conseguem através de esforço, trabalho e perseverança. Também ninguém disse que era fácil ter uma companhia e mantê-la. Pelo menos, nunca encontrei ninguém que dissesse que ia ser muito fácil, por isso já sabíamos, de certa forma, que o que estávamos a fazer era complicado.

\section{E olhando para a frente, consegue ver mais uma} década?

Não sei. Consigo ver os próximos dois anos, porque funcionamos nesse regime temporal. Mas sim, julgo que consigo ver mais uma década, embora isso também dependa se fizer ou não sentido do ponto de vista da criação. Se chegarmos a um ponto em que achamos que estamos a repetir tudo o que já fizemos antes e que não há mais nada de novo para inventar, acho que esse será o momento para terminar e ir descobrir novas coisas.

\section{Quanto a novos projectos do TdV?}

Agora acabámos o Paredes de vidro e o espectáculo vai para Guimarães. Temos o Esta é a minha cidade e eu quero viver nela em Viseu, e possivelmente também no Brasil, em Julho. Depois vamos iniciar um projecto de fundo deste ano que se chama Labor, que é sobre o trabalho; sobre a origem e a destruição do trabalho, todas essas questões prementes na nossa sociedade e vamos começar com uma apresentação no Teatro Maria Matos, no final de Julho. Vamos continuar esse projecto, ao longo do ano, em várias partes. $E_{1}$ depois, para o ano, vamos trabalhar sobre 0 amor. 